\title{
The Effect of Firm-level ESG Practices on Macroeconomic Performance
}

Xiaoyan Zhou, Ben Caldecott, Elizabeth Harnett, \& Kim Schumacher

3rd June 2020

Oxford Sustainable Finance Programme, Smith School of Enterprise and the Environment, University of Oxford | Working Paper No. 20-03

ISSN 2732-4214 (Online)

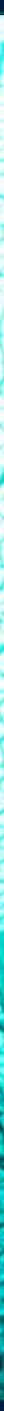


The Oxford Sustainable Finance Programme at the University of Oxford Smith School of Enterprise and the Environment is a multidisciplinary research centre working to be the world's best place for research and teaching on sustainable finance and investment. We were established in 2012 to align the theory and practice of finance and investment with global environmental sustainability.

We research environment-related risks, impacts, and opportunities across different sectors, geographies, and asset classes; how such factors are emerging and how they positively or negatively affect asset values; how they might be interrelated or correlated; their materiality (in terms of scale, impact, timing, and likelihood); who will be affected; and what affected groups can do to pre-emptively manage risk. Since our inception we have conducted pioneering research on stranded assets and continue to undertake significant research on the topic.

The production of high-quality research on the materiality of environment-related factors is a necessary, though insufficient, condition for these factors to be successfully integrated into decision-making. Consequently, we develop the data, analytics, frameworks, and models required to enable the integration of this information.

We are pioneers and advocates of 'spatial finance', a term we have coined that refers to efforts to bring geo-spatial capabilities into financial analysis. As such we are developing new asset-level datasets through data science and combining these with new approaches to spatial analysis, scenarios, and stress tests.

We also research barriers to the adoption of practices related to sustainable finance and investment. This includes the role of governance, norms, behaviour, and cognition, as well as policy and financial regulation in shaping investment decisions and capital allocation.

The Oxford Sustainable Finance Programme is based in a world leading university with a global reach and reputation. We work with leading practitioners from across the investment chain (including actuaries, asset owners, asset managers, accountants, banks, data providers, investment consultants, lawyers, ratings agencies, stock exchanges), with firms and their management, and with experts from a wide range of related subject areas (including finance, economics, management, geography, data science, anthropology, climate science, law, area studies, psychology) within the University of Oxford and beyond. The Oxford Sustainable Finance Programme's founding Director is Dr Ben Caldecott.

For more information please visit: https://www.smithschool.ox.ac.uk/research/sustainablefinance 


\section{Acknowledgements}

We would like to thank the UK Partnering for Accelerated Climate Transitions (UK PACT) China Green Finance Programme for funding this work. We would also like to thank Krister Koskelo, a D.Phil. candidate at the University of Oxford, for his research assistance, as well as the internal and external reviewers who provided many insightful comments.

\section{Supported by}

\section{UKE PACT}

\section{Suggested citation}

Zhou, X., Caldecott, B.L., Harnett, E., \& Schumacher, K. (2020), 'The Effect of Firm-level ESG Practices on Macroeconomic Performance', University of Oxford Smith School of Enterprise and the Environment Working Paper 20-03.

\section{Disclaimer}

The views expressed in this paper represent those of the authors and do not necessarily represent those of the Smith School or other institution or funder. The paper is intended to promote discussion and to provide public access to results emerging from our research. It may have been submitted for publication in academic journals. It has been reviewed by at least one internal referee before publication.

The Chancellor, Masters, and Scholars of the University of Oxford make no representations and provide no warranties in relation to any aspect of this publication, including regarding the advisability of investing in any particular company or investment fund or other vehicle. While we have obtained information believed to be reliable, neither the University, nor any of its employees, students, or appointees, shall be liable for any claims or losses of any nature in connection with information contained in this document, including but not limited to, lost profits or punitive or consequential damages. 


\title{
The Effect of Firm-level ESG Practices on Macroeconomic Performance
}

\author{
Xiaoyan Zhou ${ }^{\star}$, Ben Caldecott ${ }^{\star}$, Elizabeth Harnett ${ }^{\star}$, and Kim Schumacher ${ }^{\star \star}$ \\ *Smith School of Enterprise and the Environment, University of Oxford, ${ }^{* *}$ Tokyo Institute of Technology
}

\begin{abstract}
This paper investigates whether the development and adoption of firm-level environmental, social and governance (ESG) practices affects national macroeconomic performance, and whether this differs between developed countries and emerging economies. Using dynamic panel techniques - generalised method-of-moments (GMM) estimators - we find that an increase of micro-ESG performance can result in the improvement of living standards as measured by GDP per capita. When we test this link by country type, we find that firm-level social performance in a country is positively associated with GDP per capita in both developed countries and emerging economies. As for the other two components of firm-level ESG measures, namely environmental and governance performance, we find that these affect macroeconomic performance in emerging economies, but that the effects remain insignificant in developed countries. While further research is needed, these results may be of particular interest to policymakers and central banks, as they suggest that encouraging the adoption of ESG practices at the firm-level could support macroeconomic performance.
\end{abstract}




\section{Executive Summary}

This paper investigates the linkages between the adoption of environmental, social and governance (ESG) practices in companies and the macroeconomic performance of those firms' home countries, over the period 2002-2017. This first empirical study to examine the effect of firm-level ESG implementation on macroeconomic performance across both developed and emerging economies finds that the two are indeed positively correlated (Table A). Broadly, this finding holds across all categories, but there are some differences in the strengths of the effect when looking separately at the three constituents of ESG, or when looking separately at developed and emerging economies.

\section{Key findings:}

- Across the sample group, an increase of firms' ESG performance in a country is associated with a positive, statistically significant effect on living standards in that country, as measured by GDP per capita.

- Firms' average social performance has a statistically significant positive effect on growth in GDP per capita in both developed and emerging economies. Environmental and governance performance has a statistically significant positive effect for growth in GDP per capita in emerging but not developed economies.

Results: Our results across the whole sample group show that a one-unit increase in firms' average $\mathrm{E}, \mathrm{S}$, and $\mathrm{G}$ scores at the country-level is associated with $0.06 \%, 0.10 \%$, and $0.19 \%$ increases in the log of GDP per capita1, respectively. To put this in terms of a concrete example, if Indonesian firms (with a mean firm environment score of 43.5 ) were to raise their environmental performance to the level of the highest performers in the dataset, those of France (71.8), other things being equal, this would be associated with a $15 \%$ increase in GDP per capita, from just under US $\$ 4,300$ to just over US $\$ 4,900$.

For the 11 emerging economies in the sample, we document a statistically significant association between all three kinds of corporate ESG performance-that is, environmental, 
social and governance performance-and national economic growth per capita. For developed countries, firms' average environmental and governance performance has no statistically significant effect on national economic growth per capita, but firm-level social performance does have a significant, positive effect. A one-unit increase in mean firm social performance is associated with a $0.07 \%$ increase in the log of GDP per capita, suggesting that a rise in Japanese firms' mean social performance (44.56) to the level of Spain (67.38) would be associated with a $18.48 \%$ increase in Japan's GDP per capita, other things being equal.

Table A The results of the micro-ESG performance effect on macroeconomic growth

\begin{tabular}{|c|c|c|c|}
\hline & \multicolumn{3}{|c|}{$\begin{array}{l}\text { Percentage change in the log of GDP per capita for every one-point (out of 100) increase in } \\
\text { average } E, S \text {, and G performance }\end{array}$} \\
\hline & All countries & Developed countries & Emerging economies \\
\hline $\begin{array}{l}\text { Environment } \\
\text { performance }\end{array}$ & $\begin{array}{l}0.06 \% \text { increase. Statistically } \\
\text { significant. }\end{array}$ & $\begin{array}{l}-0.01 \% \text { increase. } \text { Not } \\
\text { statistically significant. }\end{array}$ & $\begin{array}{l}0.12 \% \text { increase. Statistically } \\
\text { significant. }\end{array}$ \\
\hline $\begin{array}{l}\text { Social } \\
\text { performance }\end{array}$ & $\begin{array}{l}0.10 \% \text { increase. Statistically } \\
\text { significant. }\end{array}$ & $\begin{array}{l}0.07 \% \text { increase. Statistically } \\
\text { significant. }\end{array}$ & $\begin{array}{l}0.11 \% \text { increase. Statistically } \\
\text { significant. }\end{array}$ \\
\hline $\begin{array}{l}\text { Governance } \\
\text { performance }\end{array}$ & $\begin{array}{l}0.19 \% \text { increase. Statistically } \\
\text { significant. }\end{array}$ & $\begin{array}{l}0.03 \% \text { increase. Not statistically } \\
\text { significant. }\end{array}$ & $\begin{array}{l}0.26 \% \text { increase. Statistically } \\
\text { significant. }\end{array}$ \\
\hline
\end{tabular}

Policy Implications: Overall, our results suggest that the higher level of corporate ESG practice is across the entire national economy, the more pronounced the positive macroeconomic effect. Our results thus refute the notion that active integration of environmental, social, or governance policies into corporate decision-making will lower GDP growth, and make a compelling case to industry stakeholders, investors, and policymakers that ESG policy implementation across the corporate sector will generate macroeconomic benefits.

This research will be of particular interest to economic policymakers as well as central banks. Policymakers have a variety of tools at their disposal to encourage the adoption of ESG practices at the firm-level and our conclusions support the view that such efforts should be 
accelerated to enhance long-run macroeconomic performance. The findings also have implications for institutions in international development, such as multilateral development banks, as our results imply that the adoption of firm-level ESG practices is not in tension with economic growth and development, but rather a way to accelerate it.

Our finding that firm-level social performance is positively associated with GDP per capita is notable in light of the ongoing Covid-19 pandemic, during which the employment practices of companies are under particular scrutiny. Our research suggests that, if some of the pandemic recovery efforts were directed at enhancing companies' ESG and especially social performance, all things being equal, this could stimulate economic growth. 


\section{Introduction}

In recent years, measuring and evaluating companies based on environmental, social, and governance (ESG) factors has become increasingly commonplace across the entire financial sector, and beyond. The Paris Climate Agreement and the United Nations Sustainable Development Goals (SDGs), both adopted in 2015, have acted as catalysts for increased adoption and monitoring of sustainable corporate practices. Initiatives such as the United Nations Principles for Responsible Investment (UN PRI), launched in 2007, have raised awareness among companies to consider ESG policies and issues as an aspect of business or risk management distinct from their general corporate social responsibility (CSR) efforts (UN PRI, 2018). A large number of companies have started to implement internal policies on key ESG themes such as transparent disclosure of impacts and risks, ESG impact measurement, data collection, and adequate reporting, for example via integrated annual reports or separate sustainability reports (Skouloudis et al., 2016; IIRC, 2015; GRI, 2019). Outside efforts to measure and monitor companies' ESG performance have proliferated, whether through the work of credit rating agencies branching out into ESG scores, or initiatives such as the Carbon Disclosure Project (CDP), which uses annual surveys to track the efforts of more than 7,000 companies in areas such as climate change and water management (CDP, 2019).

The impacts of these kinds of efforts on firm-level performance have been well documented. Several studies have found that firms that have improved their ESG outcomes, for example by reducing their carbon emissions, promoting gender and racial diversity or actively engaging with communities in which they operate, have in most cases experienced higher firm value ( $\mathrm{Yu}$ et al., 2018), better credit ratings (Devalle et al. 2017), higher productivity (Koźluk and Zipperer, 2014; Abrizio et al., 2017), greater competitiveness (Dechezleprêtre and Sato, 2017; Madsen and Ulhoi, 2017), and stronger financial performance overall (Friede et al., 2015; Lee et al., 2018). Moreover, numerous studies, reports and essays have attempted to examine the linkages between environmental or social legislation and firm-level performance (Ambec et al., 2010; Everett et al., 2010; Clark et al., 2014; Friede et al., 2015; Rubashkina et al., 2015; Cohen and Tubb, 2018; Lopez-Arceiz et al., 2017) and how macroeconomic factors affect individual firms' willingness and capacity to adopt ESG-aligned internal policies (Annicchiarico and Di Dio; 2015; Baldini et al., 2016; Mavragani et al., 2016; Lins et al., 2017; Banerjee et al, 2019). 
An area that has seen much less research is the potential influence that adoption of ESG practices at the firm-level could have on country-level, i.e. macroeconomic, performance. Several theoretical studies have made the case conceptually that ESG adoption could affect the macro-economy based on the Porter Hypothesis (Porter and Van der Linde, 1995) that firm-level ESG implementation enhances economic competitiveness and/or productivity (Everett et al., 2010; Abrizio et al., 2017; Dechezleprêtre and Sato, 2017; Cohen and Tubb, 2018). Expanding on this notion, gains in productivity (Abrizio et al., 2017) and competitiveness (Dechezleprêtre and Sato, 2017; Cohen and Tubb, 2018) are based on established economic theory, ultimately translating into stronger net economic growth (Kordalska and Olczyk, 2016). However, empirical studies on this topic remain remarkably scarce. To our knowledge, only one other study by Skouloudis et al. (2016) has looked at the potential links between CSR practices and national competitiveness, but it only focused on European countries.

This paper is therefore the first empirical study to examine the effect of firm-level ESG implementation on macroeconomic performance across both developed and emerging economies. We examine the period 2002-2017. We apply dynamic panel generalised methodof-moments (GMM) techniques to correct any potential bias resulting from omitted variables, simultaneity, or unobserved country-specific effects. This paper employs two available dynamic panel GMM estimators: 1) the 'difference GMM' estimator developed by Arellano and Bond (1991), and 2) the 'system GMM' estimator developed by Blundell and Bond (1998) and Arellano and Bover (1995). Both reference methods produced consistent results.

We find that an increase in micro-ESG performance can, generally speaking, result in the improvement of living standards, as measured by GDP per capita. We then investigate whether the micro-ESG performance effect varies across markets. We show that for the 19 developed countries in our sample, firm-level environmental and governance performance has no statistically significant effect on national economic growth, whereas firm-level social performance does have a significant, positive impact on GDP per capita. Among emerging economies, we document a strong and significant association between all three kinds of ESG performance-that is, environmental, social and governance performance-and national economic growth. These results imply that firms' ESG policies do not only matter in developed countries (which generally have integrated ESG policies more broadly), but could improve macroeconomic performance in emerging economies as well. This study increases the scope 
of prior studies by providing the first evaluation of the effects of firm-level ESG performance on macroeconomic performance across the most significant global economies. It also extends the coverage period and overall data granularity, hence providing the most up-to-date and detailed empirical evidence on this topic.

This paper starts by providing a literature review of previous studies and results regarding the effects of firm-level ESG implementation on economic parameters. It then sets out our core hypothesis: that countries with higher levels of firm-level ESG practice adoption have experienced stronger macroeconomic performance. Afterwards, we present our data, which was sourced primarily from the Thomson Reuters Asset4 ESG scores, and our methodology, centred around dynamic panel GMM techniques to correct potential bias introduced by unobserved country-specific effects or the endogeneity of explanatory variables. The subsequent results section, which includes a robustness test section, proves our initial theory insofar as we find strong evidence that, in general, firm-level social performance in a country is positively associated with GDP per capita for all sample countries. The final section addresses some of the methodological shortcomings and questions that fell out of the scope of our current study, and which could be addressed in future research. Finally, the analysis concludes by discussing the broader policy implications of our findings.

\section{Literature review and hypothesis development}

\subsection{Why Do Firm-Level ESG Practices Matter?}

In the context of globalisation, economic liberalisation and privatisation, there has been a shift in the burden of responsibility away from government institutions towards the corporate realm (Hughes, Buttle, and Wrigley 2007). The overall concept of ESG, and the notion that firms should adopt better ESG practices, have gained more traction as environmental and corporate governance issues alike have frequently led to massive losses, or even insolvency, for several large firms (Ribando and Bonne, 2010). ESG is shorthand for environment, society (or social) and governance; measuring a company on its ESG performance encompasses considering the impact of business and investment activities on the environment and society (for the "E" and "S"), and looking at that company's internal governance structures (for "G"). These are increasingly seen as the key ways to measure the non-financial performance of the company (Atan et al. 2018). Corporate action on ESG issues has increased dramatically over the past 
two decades (PWC 2010; Murray, 2012). Under the UN Global Compact, launched in 2000, 14,429 companies in more than 160 countries2 have pledged to align their operations with ten principles covering human rights, labour conditions, environmental protection and anticorruption measures. Firms have a significant impact on the environment and society through the production of vital goods and services, but also have the power to influence consumer behaviour, invest in innovation, and lobby governments for greater action on important issues. Corporate supply chains make up the distribution channels of products, from the site(s) of their source material to the delivery to the end consumer. Firm-wide ESG strategies at multinational firms can raise international levels of sustainability by implementing higher corporate standards, above and beyond local standards (Angel and Rock, 2005). Corporations are thus key to initiating change on a global scale (Clark and Hebb, 2005; Porter and Kramer, 2006; Becker-Olsen, Cudmore, and Hill, 2006), but could they also have the potential to impact national levels of productivity and competitiveness? The investment community in particular sees ESG issues as important, and, increasingly, as financially "material" to an investment portfolio (Richardson 2009; Clark, Feiner, and Viehs, 2014). If these factors are material to investment returns, then they are perhaps likely to be relevant to national-scale economic risk and returns as well.

While the literature tends to group environmental, social, and governance issues together, there remains some debate around the validity of this grouping. While the geographic literature tends to focus more on environmental and social issues, the European Center for Corporate Engagement (ECCE) found that investors use corporate governance factors most often in their decision-making processes (Jaworski, 2007). It could therefore be argued that governance should, perhaps, be detached from E and S. However, this study will use the term ESG, in accordance with the majority of literature, but recognises that they are separate entities, and that while they should not entirely be separated, a deeper understanding of sustainability requires individual examination of the components, an approach that is incorporated into this study. Indeed, this study seeks to pre-empt some common criticisms of ESG research: many studies pick and choose among the various ESG dimensions (Uecker-Mercado and Walker, 2012) whereas we have sought to provide insight into each constituent part separately and collectively. Furthermore, the majority of ESG research uses data from only, or mainly, the US, 
sometimes with the addition of UK data (Renneboog, Horst, and Zhang, 2008). Whereas that approach limits the understanding of ESG behaviour to very few specific countries, this research extends to 38 countries globally.

\subsection{Link between ESG performance and financial outperformance}

A large and growing academic literature has explored the numerous ways in which ESG issues can affect firm-level financial performance. Porter and van der Linde (1995) explore the competitive advantages available through environmental innovation, Clark and Hebb (2005) point to the lower reputational and environmental risk factors involved in more responsible companies, while Nahal and Lucas-Leclin (2013) highlight the negative impact on supply chains from rising climate anomalies. Lee, Cin, and Lee (2016) find that there is a significant positive correlation among corporate environmental responsibility performance, returns on equity, and returns on assets. In terms of social performance, Barnett and Salomon (2012) also find that companies that perform well on measures of corporate social responsibility also attain higher financial performance. Nollet, Filis, and Mitrokostas (2016) believe that an enterprise that incorporates the fulfilment of social responsibility as a part of its strategic planning can thereby make itself more enticing to consumers and investors, thus creating extra value for its products. Regarding the corporate governance effect on financial performance, Masulis, Wang, and Xie (2007) find that poor governance in companies usually correlates with poor acquisition decisions, thus reducing such firms' market value.

In contrast to the evidence in favour of the positive impacts of ESG practices, some researchers document that ESG adoption can reduce firm value, as adhering to a higher level of ESG standards entails extra costs. Brammer, Brooks, and Pavelin (2006) find that there is a negative correlation between corporate social performance indicators and share returns. Duque-Grisales and Aguilera-Caracuel (2019) also document a significant negative relation between ESG performance and financial performance, both individually and in combination.

Although the findings of existing literature are not unanimous, there is growing evidence for ESG having a positive or non-negative financial impact. For useful meta-analysis and summary of previous research, see Friede et al. (2015) and Clark et al. (2014). Despite growing evidence, some scholars still question this link, mostly on the basis of arguments concerning 
methodological and data quality issues (Margolis and Walsh 2003; Garcia-Castro, Ariño, and Canela 2010).

The reasons why companies decide to adopt ESG have also been discussed (Bansal and Roth, 2000; Hedberg and Von Malmborg, 2003; Kim and Statman, 2012), with Porter and Kramer (2006) arguing that there are moral, financial, brand reputation, and legal reasons. Milton Friedman (1970) suggested that corporations were primarily responsible for providing shareholders with maximum profit; but in recent times, strong ESG alignment is increasingly seen as making good business sense (Wilmshurst and Frost, 2000; Clark and Hebb, 2005; Willard, 2012). Sustainable companies appear to have a lower risk factor, and offer potentially better long-term investing strategies (MSCI, 2017a; Della Croce, Stewart, and Yermo, 2011; Clark and Hebb, 2004). ESG can also act as a proxy for assessing the quality of management within a company (Greenwald, 2009).

\subsection{Hypothesis Development}

To date, few academic studies have sought to scale-up firm-level ESG performance to the national-level, or relate it to macroeconomic performance. Important exceptions to the lack of research include work on the link between CSR and national competitiveness, including Boulouta and Pitelis (2014), European Commission (2008a; 2008b), and Zadek (2006) who all find positive correlations, through both empirical and theoretical discussions. No research has sought to directly establish a relationship between firm-level corporate ESG performance, individually, and GDP, as we do in this research, though Boulouta and Pitelis (2014) did include GDP (perhaps erroneously) in their calculations for competitiveness. Interestingly, in a sample of Asian countries, Chapple and Moon (2005) found that there was no statistically significant correlation between Gross National Product (GNP) and CSR activity, with economic development not a driver of ESG, a claim which was also discussed in Ringov and Zollo (2007). Boulouta and Pitelis (2011) document a positive relationship between firm-level CSR practices and national competitiveness. However, that result is drawn on questionnaire survey data, which served as a proxy for CSR performance; moreover, the study only focused on developed countries for a six-year period at the earlier stage of CSR development.

National GDP is a measure of the market value of all goods and services produced in a country, and it can therefore be hypothesised that ESG incorporation by companies in a given country, 
leading to better performance, could thereby also boost GDP. This is linked to the concept of 'responsible competitiveness', defined as 'an economy's productivity being enhanced by businesses taking explicit account of their social, economic, and environmental performance' (MacGillivray, Sabapathy, and Zadek, 2003). These arguments have led us to propose the following hypotheses:

\section{H1: Firm-level environmental performance positively affects a country's GDP per capita}

\section{H2: Firm-level social performance positively affects a country's GDP per capita}

\section{H3: Firm-level governance performance positively affects a country's GDP per capita}

There are several difficulties in attempting such a study, highlighted in previous academic literature. These include the challenges inherent in scaling microeconomic, firm-level factors to the national level (Swift and Zadek, 2002; Frynas, 2008; European Commission, 2008b; Kwarteng, Dadzie, and Famiyeh, 2016), particularly as productivity is often driven by the action of complex, multinational firms. Research has illustrated a range of factors that prevent microlevel CSR scaling up to the national economy, including: the possibility of CSR benefits harming national economies even as they benefit individual companies, and potential distortions to trade flows caused by CSR practices that lead to new standards and changes in consumer or corporate expectations (Swift and Zadek, 2002; Boulouta and Pitelis, 2014). Hence, much of the literature tends to emphasize the importance of macro-level, rather than firm-level, factors to explain national productivity and competitiveness, as there are inherent problems with aggregating corporate performance (e.g. size, scope and performance differentials) (Schwab, 2018; Aiginger, 2006). Further, the definitional and data measurement problems of ESG performance at the national-level have led some researchers to focus only on specific areas, such as environmental performance (Porter and van der Linde, 1995; Etsy et al. 2005; Skouloudis, Isaac, and Evaggelinos, 2016). It is notable that several ESG data providers have also started to offer country-level macroeconomic growth scores based on aggregated ESG performance indicators. For example, Beyond Ratings states that their country growth potential scores are based on an "econometric model, using PCA and PLS regressions to determine the materiality of $229 \mathrm{E}, \mathrm{S}$ and G factors." (Beyond Ratings, 2019). Our study instead aims to test the link between firm-level ESG integration and macroeconomic growth. 


\section{Data and Methodology}

This section documents our variables, data sources, and methods of analysis. While the majority of our data sources are publicly available, we are, to the best of our knowledge, the first to investigate specifically how firm-level ESG performance influences national-level economic growth across a range of economies.

\subsection{Data}

\subsubsection{Firm-level ESG Performance}

In conducting this research, we employ average firm-level ESG scores in a country as an indicator of microeconomic ESG performance. The scores were sourced from the Thomson Reuters Asset4 database, which has been widely used throughout previous studies (Eccles et al., 2014; Ioannou and Serafeim, 2012; loannou et al., 2014). This database incorporates more than 400 ESG metrics across 10 different ESG topics (see Appendix 1), derived from sources including firms' annual reports, company CSR websites, and newspaper articles. The Thomson Reuters ESG scores cover over 6,500 companies globally for a period ranging from 2002 to 2017, which allows us to perform a statistical analysis in a global context for the last 15 years. Firm-level E, S, G performance values range from 0 to 100 , with 100 as the highest score. We use the Asset4 company ESG scores to construct an equally weighted mean of $E$, $\mathrm{S}$, and $\mathrm{G}$ scores separately by country at year $t$ that measures the average microeconomic $\mathrm{E}$, $\mathrm{S}$, and $\mathrm{G}$ performance of firms based in a given country, for all observed countries and times.

Using the mean of publicly listed firm ESG scores in a country as an indicator of national microESG performance is not ideal, but given data limitations on ESG performance for non-listed companies we argue that it is an important way of beginning to test our hypotheses. We acknowledge that the use of large listed firms in scaling microeconomic factors to the countrylevel may create measurement biases, as multinational firms often set up part of business activities in other markets. However, institutional theory argues that organisations that operate beyond their home region need to gain the organisation's legitimacy in the foreign markets where they operate (Kostova and Zaheer 1999). These organizations must adapt to the expectations of their host regions, which make companies adopt local ESG practices and requirement (Berrone and Gomez-Mejia 2009; Deephouse and Suchman 2008). Asset4 firm 
level ESG scores in a country are, therefore, likely to largely represent the level of firm-level ESG performance in that country.

In total, excluding Hungary and Czech Republic, each of which contain fewer than ten firms, we obtained the average of E, S, and G corporate scores over the 2002-2017 period for 30 countries, grouped into 19 developed countries and 11 emerging countries, applying the $\mathrm{MSCl}$ Country Classification Standard (MSCI, 2017b). The list of countries and the number of firms included per country are shown in Table 1. Column (1) and (2) report the mean and standard deviations of the environmental scores by country for the sample period of 2002-2017. Column (3) to Column (6) present the mean and standard deviations of the social and governance scores, respectively. Column (7) shows the number of listed firms included in the Asset4 database. It is worth noting that in general, developed countries have much higher environmental and social scores than emerging economies and the latter are much more volatile than the former during our sample period, suggesting that firms from developed markets perform much better than those from emerging economies. The governance performance follows a similar pattern; however, it exhibits relatively low variations between the two economic groups.

\subsubsection{Macroeconomic Performance}

This paper employs a widely-used measure of macroeconomic performance: Gross Domestic Product (GDP) per capita (Barro, 2006; Grossman and Krueger, 2006; Jones, 2016; Wong et al., 2005). GDP per capita is downloaded from the World Bank database3. It is the rate of GDP to midyear population and measures the change or trend in a nation's living standards over time. Despite arguments that GDP-based measures are potentially not always the most relevant indicators of economic performance for all economies, GDP data are nonetheless arguably more reliable than national accounts data due to variations in definitions, method, and reporting standards.

3 The World Bank measures GDP at purchasing price parity (PPP). Further, the calculation includes gross value added by all resident producers in the economy plus any product taxes and minus any subsidies not included in the value of the products. See:

https://data.worldbank.org/indicator/NY.GDP.MKTP.CD 


\subsubsection{Control Variables}

To improve the robustness of our analysis, we control for a selection of macro-factors that have been associated with national economic growth. As both prior theoretical and empirical studies have pointed to a positive relationship between financial development and economic growth (Arestis et al., 2006; Durusu-Ciftci et al., 2017; Arellano and Bover, 1995), we control for total market value, which is the total market capitalisation of listed domestic companies in a country. Following existing studies linking foreign direct investment (FDI) and economic growth (Alfaro et al. 2004; E. Borensztein and De Gregorio, 2013; De Mello, 2002), we control for net FDI in our sample. We also include a measure of the consumer price index (CPI) to control for inflation. Table 2 presents a summary of the variables used in this study. Column (1) to (4) show each variable's name, definition, measurement, and data source, respectively.

\subsection{Methodology}

For our analysis, we need to address the potential impact of unobserved heterogeneity in the panel data. The application of within transformation in regression models, such as fixed effect and first difference, can take account of these data-specific aspects, but the demeaning process introduces a correlation between the lagged dependent variable and the error, and yields a biased coefficient (Nickell, 1981). We instead use dynamic panel generalised methodof-moments (GMM) techniques to correct potential bias induced by unobserved countryspecific effects and endogeneity of explanatory variables.

There are two types of dynamic panel GMM methods, the 'difference GMM' estimator developed by Arellano and Bond (1991,) as well as the 'system GMM estimator' developed by Blundell and Bond (1998), and Arellano and Bover (1995). In the 'difference GMM' framework, Arellano and Bond (1991) partially dismantle the regression equation to remove time invariate fixed effects and then instrument the first-differenced variables using lagged values of the original regressors to eliminate potential parameter inconsistency arising from simultaneity bias. This approach has increasingly been used in macroeconomic growth studies (Benhabib and Spiegel 2000; Banerjee and Duflo 2003; Easterly and Levine 1997) since its first application by Caselli, Esquivel, and Lefort (1996). Building on the work of Arellano and Bover (1995), Blundell and Bond (1998) proposed a 'system GMM' estimator, which was designed 
to address weak instrument concern when the dependent variable is close to a random walk and the lagged values of financial development capture little information of future changes.

Based on Arellano and Bond's (1991) work, we estimate the dynamic panel data model that is specified as follows:

$$
\begin{aligned}
\text { MacroPerform }_{i, t} & =\beta_{1} \text { MacroPerform }_{i, t-1}+\beta_{2} \text { ESG_Score }_{i, t}+\beta_{3} \text { Controls }_{i, t}+\beta_{4} \text { Yr2008 }_{i}+\beta_{5} \text { Yr2009 }_{i}+\beta_{6} \text { Year }_{i, t}+\sigma_{i} \\
& +\varepsilon_{i, t}
\end{aligned}
$$

Whereas MacroPerform M $_{i, t}$ is the outcome variable - the natural logarithm of GDP per capita for country $i$ at year t. MacroPerform Mat-1 $_{i, t}$ is the value of the natural logarithm of GDP per capita in the previous year $t-1$. We use GDP per capita as a proxy of macroeconomic performance. Controls $s_{i, t}$ include a set of factors that could influence national economic performance. They are the logarithm of total market value, net foreign direct investment (FDI), and CPI. $\operatorname{Yr} 2008$ and $\operatorname{Yr} 2009$ dummies are added to reflect the unique macroeconomic conditions during the 2008 financial crisis and the subsequent economic downturn. The time trend variable Year is also included to capture macroeconomic cycle effects. $\sigma_{i}$ is a timeinvariant unobservable and $\varepsilon_{i, t}$ is a time-varying unobservable. We take the first difference to remove the country-specific fixed effect and then use one lag of the exogenous variable as the instrument set.

\section{Results}

We first report the basic summary statistics of the aforementioned variables (Table 3). Our panel data covers 30 countries over the 2002-2017 period, with a total number of 450 countryyear observations. We decompose the standard deviation, minimum values and maximum values into 'between' and 'within' components for all variables. The mean of the environmental score is 55.556, with a minimum value of 31.697 and a maximum value of 81.940 . The standard deviations between and within countries are 7.534 and 7.796 respectively, indicating that the environmental score is quite dispersed between countries as well as over the 2002 to 2017 sample period. The distribution of the social score exhibits similar features. Differing from both the environmental and social performance scores, the governance score is much less volatile both across and within countries. Looking at GDP per capita, the between and within 
standard deviations are 2.045 and 0.123 respectively, which suggests that there is a greater variation between than within countries. The correlation matrices for all variables are presented in Table 4.

Table 5 presents the result of the overall performance of the ESG score effect on macroeconomic performance on a global scale. The estimates of the 'difference GMM' estimator show that a one point (out of 100) increase of the average $E, S$, and G performance leads to $0.06 \%, 0.09 \%$ and $0.16 \%$ increases in the log of GDP per capita, respectively. The 'system GMM' estimator produces consistent results, whereby a one point (out of 100) increase of the average $E, S$, and G performance leads to $0.06 \%, 0.10 \%$ and $0.19 \%$ increases in the log of GDP per capita, respectively. Our results indicate that an increase in firm-level environmental, social, or governance performance can result in improvement in living standards respectively, as measured by GDP per capita. The size of the resulting growth is both statistically and economically significant. After controlling for country-specific effects, endogeneity, and macroeconomic cycle effects, the panel analysis suggests that microeconomic, firm-level ESG practices exert a positive influence on macroeconomic development.

In Table 6 we examine more closely the question of whether increases in firm-level ESG performance are related to an improvement of macroeconomic growth in developed countries. The results in columns (1) to (3) show that for the observed 19 developed countries, firm-level environmental and governance performance have no statistically significant effect on national economic growth, whereas firm-level social performance does have a significant impact on GDP per capita. For every one point (out of 100 ) increase in the average social performance during the sample period, we observed a $0.07 \%$ increase in GDP per capita. These results confirm our original hypothesis and strengthen the notion that firm-level ESG measures can factor into macroeconomic performance. This finding is consistent with Skouloudis et al. (2016), who found that there was a positive, albeit weak, correlation between firm-level CSR policies and GDP growth. The limited geographic scope and time period covered in that study resulted in a low number of observations, which reduces the explanatory value of its findings considerably. Our results further confirm previously documented evidence that firms' environmental and social performance do influence macroeconomic performance indicators. Abrizio et al. (2017) and Dechezleprêtre and Sato (2017) hinted at the notion that their findings 
could also bear relevance in the context of overall GDP growth; however, their studies were limited to competitiveness or productivity as dependent variables.

Following the developed country analysis, we then investigate the research question in the context of emerging economies, significantly expanding the scope of previous findings that either focused solely on developed economies (Rubashkina et al., 2015; Ahn and Kim, 2015; Skouloudis at al., 2016; Korez-Vide and Tominc, 2016; Abrizio et al., 2017) or on emerging ones (Ngobo and Fouda, 2012; Fayissa and Nsiah, 2013); some previous analyses further limited themselves to just country- or region-specific case study analyses (Zárate-Marco and Vallés-Giménez, 2015; Lee et al., 2016; Devalle et al., 2017). Columns (4) to (6) in Table 6 present our results, showing a strong and significant association between micro-level environmental, social and governance development and national economic benefits as measured by GDP per capita. These results strengthen the notion that ESG policies do not only impact developed countries, which generally have integrated ESG policies more broadly, but improve macroeconomic performance in emerging economies as well. Ngobo and Fouda (2012) and Fayissa and Nsiah (2013) observed similar macroeconomic trends for African countries with governance as the primary determining factor. Moreover, Kordalska and Olczyk (2016) found that elevated competitiveness scores are successful predictors of economic growth for the majority of low-income countries, as well as for several large middle-income countries such as China and India.

\section{Robustness Tests}

We performed a series of robustness tests. Table 7 reports the results of the firm-level ESG performance effect on macroeconomic development for the whole sample using two-year lagged dynamic GMM estimators. The results are consistent with the one-year lagged GMM estimator tests. We also examine the firm ESG performance effect on the unemployment rate using both the 'difference GMM' estimator and the 'system GMM' estimator, with results reported in Table 8. The finding suggests that a higher level of environmental and social performance significantly reduces unemployment rates. The correlation between environmental and social scores and the unemployment rate may help to explain our main finding that firm-level adoption of ESG practices contributes to improvement in GDP per capita. 
Furthermore, we included several more controls such as government expenditure, R\&D expenditure, and financial structure in the GMM estimators. With these additional controls, we obtained identical, statistically significant estimates to those reported in Table 5 and 6 . We also conducted a serial correlation test. The output suggested no evidence of second-order serial correlation, thus satisfying the Arellano-Bond model assumptions.

\section{Discussion and Policy Implications}

The results presented in this paper deliver the most comprehensive link to date between firmlevel ESG efforts and macroeconomic growth. Given the robustness of our data observations in terms of time period and breadth of geographic coverage, our findings add to the existing literature by not only looking at how firm-level performance affects macroeconomic performance factors such as competitiveness or productivity, but how it actually impacts overall national growth figures. This paper acts as an aggregate study by taking account of factors and variables presented in prior literature (Eccles et al., 2014; Friede et al., 2015; Skouloudis et al., 2016; Kordalska and Olczyk, 2016; Cohen and Tubb, 2018), which as outlined in the literature review, remained incomplete in terms of drawing a link between ESG implementation at the firm-level and macroeconomic performance. Our results further substantiate the overall theories explored in previous studies. Echoing some of the underlying characteristics outlined by Arellano and Bover (1995), Eccles et al. (2014), Friede et al. (2015), Skouloudis et al. (2016), and Cohen and Tubb (2018), our findings refute the notion that active integration of environmental or social policies into corporate decision-making will lower GDP growth. Although this paper has applied a more granular approach than Skouloudis et al. (2016), by incorporating data from additional sources besides composite indices, this paper has not created individual country growth profiles. It has instead chosen to divide them into three groups, the first being developed countries (Table 6), the second emerging economies (Table 6 ), and the last a composite group of all countries (Table 5).

Our results make a compelling case to industry stakeholders, investors, and policymakers that ESG policy implementation across the corporate sector will generate macroeconomic benefits. Fostering business and regulatory environments that facilitate the implementation of ESG policies could lead to higher growth as compared to business-as-usual scenarios. Theoretical innovators in this space, including Porter and Van der Linden (1995), Wilmshurst and Frost 
(2000), and Clark and Hebb (2005), have shown that stringent economic policies do not necessarily stifle economic growth, either at the micro- or macro-levels. Companies that proactively adopt more progressive internal ESG policies will over the medium- to long-term experience less violent fluctuations during economic downturns, and more solid growth during periods of increased economic expansion (Harrison and Berman, 2015; Annicchiarico and Di Dio, 2015; Lins et al., 2017). Furthermore, our results suggest that the higher the level of corporate ESG practice is across the entire national economy, the more pronounced the positive macroeconomic lever effect.

Our conclusions will be of particular interest to policymakers in developed or developing countries, who are responsible for long-run economic performance, as well as central banks interested in how the macro-economy will perform and its implications for monetary policy.

Policymakers have a variety of tools at their disposal to encourage the adoption of ESG practices at the firm-level and our conclusions support the view that such efforts should be accelerated to enhance long-run macroeconomic performance. Our finding that firm-level social performance is positively associated with GDP per capita in both developed countries and emerging economies is particularly interesting in light of Covid-19, where the employment and community practices of companies are under particular scrutiny. Our research suggests that policymakers might want to use post-Covid recovery bailouts and stimulus to enhance company ESG performance, particularly social performance in developed economies, through conditionality associated with any concessional financing provided.

The findings also have potential implications for the practices of actors who are in part responsible for supporting international development, such as multilateral development banks (e.g. World Bank, Asian Development Bank, Inter-American Development Bank) and international financial institutions (e.g. IMF), as well as multilateral development agencies (e.g. UNDP) and policy fora (e.g. OECD). Promoting the adoption of firm-level ESG practices is not in tension with economic growth and development, but rather is a way to accelerate it.

There are many important further questions that policymakers and researchers should explore: How do firm-level ESG practices affect other aspects of macroeconomic performance, including unemployment? Which ESG practices in particular are the most effective at generating changes that result in improvements in macroeconomic performance and how does 
this differ by country context? Are the outcomes of better ESG practices, including lower pollution, the drivers of better macroeconomic performance, or is it the improved performance of the firm, or a combination of both?

There are many others, but this is certainly an area that has direct implications for policy and one that is particularly relevant today as governments around the world seek to recover from an unprecedented demand and supply shock created by a global pandemic. 


\section{References}

Aiginger, Karl. 2006. "Competitiveness: From a Dangerous Obsession to a Welfare Creating Ability with Positive Externalities." Journal of Industry, Competition and Trade 6 (2): 161-77. doi:10.1007/s10842-006-9475-6.

Ahn, S.H., Kim, S.W., 2015. "Social investment, social service and the economic performance of welfare states." International Journal of Social Welfare 24(2): 109-119. https://doi.org/10.1111/ijsw.12094

Albrizio, S., Kozluk, T., Zipperer, V., 2017. "Environmental policies and productivity growth: Evidence across industries and firms." Journal of Environmental Economics and Management 81, 209-226. https://doi.org/10.1016/j.jeem.2016.06.002

Alfaro, Laura, Areendam Chanda, Sebnem Kalemli-Ozcan, and Selin Sayek. 2004. "FDI and Economic Growth: The Role of Local Financial Markets." Journal of International Economics 64(1), 89-112. doi:10.1016/S0022-1996(03)00081-3.

Ambec, S., Cohen, M.A., Elgie, S., Lanoie, P., 2013. "The porter hypothesis at 20: Can environmental regulation enhance innovation and competitiveness?" Review of environmental economics and policy 7(1): 2-22. https://doi.org/10.1093/reep/res016

Angel, D P, and M T Rock. 2005. "Global Standards and the Environmental Performance of Industry. Environment and Planning A ." Environment and Planning A 37 (11): 1903-18.

Annicchiarico, B., Di Dio, F., 2015. "Environmental policy and macroeconomic dynamics in a new Keynesian model." Journal of Environmental Economics and Management 69: 121. https://doi.org/10.1016/j.jeem.2014.10.002

Arellano, Manuel, and Stephen Bond. 1991. "Some Tests of Specification for Panel Data: Monte Carlo Evidence and an Application to Employment Equations." The Review of Economic Studies 58 (2): 277. doi:10.2307/2297968.

Arellano, Manuel, and Olympia Bover. 1995. "Another Look at the Instrumental Variable Estimation of Error-Components Models." Journal of Econometrics 68 (1): 29-51. doi:10.1016/0304-4076(94)01642-D.

Arestis, Philip, Panicos O. Demetriades, and Kul B. Luintel. 2006. "Financial Development and Economic Growth: The Role of Stock Markets." Journal of Money, Credit and 
Banking, 16-41. doi:10.2307/2673870.

Baldini, M., Mazzi, F., Terzani, S., Maso, L.D., Liberatore, G., 2016. "Role of Country- and Firm-Level Determinants in Environmental, Social, and Governance Disclosure." Journal of Business Ethics 150(1): 79-98. https://doi.org/10.1007/s10551-016-3139-1

Banerjee, Abhijit V., and Esther Duflo. 2003. "Inequality and Growth: What Can the Data Say?" Journal of Economic Growth 8(3): 267-299. doi:10.1023/A:1026205114860.

Banerjee, R., Gupta, K., Mclver, R., 2019. "What matters most to firm-level environmentally sustainable practices: firm-specific or country-level factors?" Journal of Cleaner Production 218, 225-240. https://doi.org/10.1016/j.jclepro.2019.02.008

Bansal, Pratima, and Kendall Roth. 2000. "Why Companies Go Green: A Model of Ecological Responsiveness." Academy of Management Journal 43 (4): 717-36. doi:10.2307/1556363.

Barro, Robert J. 2006. "Economic Growth in a Cross Section of Countries." The Quarterly Journal of Economics 106(2): 407-443. doi:10.2307/2937943.

Becker-Olsen, Karen L., B. Andrew Cudmore, and Ronald Paul Hill. 2006. "The Impact of Perceived Corporate Social Responsibility on Consumer Behavior." Journal of Business Research 59 (1): 46-53. doi:10.1016/j.jbusres.2005.01.001.

Benhabib, Jess, and Mark M. Spiegel. 2000. "The Role of Financial Development in Growth and Investment." Journal of Economic Growth 5(4): 341-360 doi:10.1023/A:1026599402490.

Berrone, Pascual, and Luis R. Gomez-Mejia. 2009. "Environmental performance and executive compensation: An integrated agency-institutional perspective." Academy of Management Journal 52(1):103-126.

Beyond Ratings. 2019. ESG Performance of Economies. https://beyondratings.com/analytics/esg-performance-of-economies/

Blundell, Richard, and Stephen Bond. 1998. "Initial Conditions and Moment Restrictions in Dynamic Panel Data Models." Journal of Econometrics 87(1):115-143 doi:10.1016/S0304-4076(98)00009-8.

Borensztein E., De Gregorio J., \& Lee J-W.. 2013. "How Does Foreign Direct Investment 
Affect Economic Growth." Journal of International Economics 45(1): 115-135 doi:10.1016/S0022-1996(97)00033-0.

Boulouta, loanna, and Christos N. Pitelis. 2014. "Who Needs CSR? The Impact of Corporate Social Responsibility on National Competitiveness." Journal of Business Ethics 119 (3): 349-64.

Caselli, Francesco, Gerardo Esquivel, and Fernando Lefort. 1996. "Reopening the Convergence Debate: A New Look at Cross-Country Growth Empirics." Journal of Economic Growth 1(3): 363-389. doi:10.1007/BF00141044.

CDP (Climate Disclosure Project). 2019. Our vision and mission. https://www.cdp.net/en/info/about-us

Chapple, Wendy, and Jeremy Moon. 2005. "Corporate Social Responsibility (CSR) in Asia a Seven-Country Study of CSR Web Site Reporting." Business and Society 44(4): 415441. doi:10.1177/0007650305281658.

Clark, G. L., A Feiner, and M Viehs. 2014. "From the Stockholder to the Stakeholder: How Sustainability Can Drive Financial Outperformance." Oxford: Smith School of Enterprise and the Environment.

Clark, G. L., and Tessa Hebb. 2005. "Why Should They Care? Corporate Responsibility and Global Standards." Environment and Planning A 37 (11): 2015-31.

Clark, Gordon L, and Tessa Hebb. 2004. "Pension Fund Corporate Engagement: The Fifth Stage of Capitalism." Relations Industrielles / Industrial Relations 59 (1): 142-71. doi:10.7202/009130ar.

Cohen, M.A., Tubb, A., 2018. "The Impact of Environmental Regulation on Firm and Country Competitiveness: A Meta-analysis of the Porter Hypothesis. " Journal of the Association of Environmental and Resource Economists 5(2): 371-399.. https://doi.org/10.1086/695613

Dechezleprêtre, A., Sato, M., 2017. "The impacts of environmental regulations on competitiveness." Review of Environmental Economics and Policy11(2):183-206. https://doi.org/10.1093/reep/rex013 
Deephouse, David L., and Mark Suchman. 2008. "Legitimacy in organizational institutionalism." The Sage handbook of organizational institutionalism 49:77.

Della Croce, Raffaele, Fiona Stewart, and Juan Yermo. 2011. "Promoting Longer-Term Investment by Institutional Investors." OECD Journal: Financial Market Trends 2011 (1): 145-64. doi:10.1787/fmt-2011-5kg55b0z1ktb.

Devalle, A., Fiandrino, S., Cantino, V., 2017. "The Linkage between ESG Performance and Credit Ratings: A Firm-Level Perspective Analysis." International Journal of Business and Management 12(9) https://doi.org/10.5539/ijbm.v12n9p53

Durusu-Ciftci, Dilek, M. Serdar Ispir, and Hakan Yetkiner. 2017. "Financial Development and Economic Growth: Some Theory and More Evidence." Journal of Policy Modeling 39(2): 290-306. doi:10.1016/j.jpolmod.2016.08.001.

Easterly, William, and Ross Levine. 1997. “Africa's Growth Tragedy: Policies and Ethnic Divisions." Quarterly Journal of Economics. doi:10.1162/003355300555466.

Eccles, R G, I loannou, and George Serafeim. 2014. "The Impact of Corporate Sustainability on Organizational Processes and Performance." Management Science. Vol. 60. doi:10.1287/mnsc.2014.1984.

EC (European Commission). 2019. Sustainable Finance. https://ec.europa.eu/info/businesseconomy-euro/banking-and-finance/sustainable-finance_en

Etsy, A., C. Daniel, M. Levy, T. Srebotnjak, and A. De Sherbinin. 2005. "Environmental Sustainability Index: Benchmarking National Environmental Stewardship." New Haven: Yale Center for Environmental Law \& Policy, 47-60.

European Commission. 2008a. "Communication from the Commission on the European Competitiveness Report 2008." Brussels.

—_. 2008b. "European Competitiveness Report 2008." Luxemburg.

Everett, T., Ishawaran, L., Ansaloni, G.P., Rubin, A., 2010. "Economic growth and the environment." MPRA Paper, University Library of Munich, Germany, https://EconPapers.repec.org/RePEc:pra:mprapa:23585.

Fayissa, B. and Nsiah, C., 2013. "The Impact of Governance on Economic Growth in Africa." The Journal of Developing Areas 47, 91-108. 
Friede, Gunnar, Timo Busch, and Alexander Bassen. 2015. "ESG and Financial

Performance: Aggregated Evidence from More than 2000 Empirical Studies." Journal of Sustainable Finance \& Investment 5 (4). Taylor \& Francis: 210-33. doi:10.1080/20430795.2015.1118917.

Friedman, Milton. 1970. "The Social Responsibility of Business Is to Increase Its Profits." New York Times, September 13.

http://www.colorado.edu/studentgroups/libertarians/issues/friedman-soc-respbusiness.html.

Frynas, Jędrzej G. 2008. "Corporate Social Responsibility and International Development: Critical Assessment." Corporate Governance: An International Review 16 (4): 274-81. doi:10.1111/j.1467-8683.2008.00691.x.

Garcia-Castro, Roberto, Miguel A. Ariño, and Miguel A. Canela. 2010. "Does Social Performance Really Lead to Financial Performance? Accounting for Endogeneity." Journal of Business Ethics 92 (1): 107-26. doi:10.1007/s10551-009-0143-8.

GRI (Global Reporting Initiative). 2019. GRI and Sustainability Reporting. https://www.globalreporting.org/information/sustainability-reporting/Pages/gristandards.aspx

Grossman, G. M., and A. B. Krueger. 2006. "Economic Growth and the Environment." The Quarterly Journal of Economics 10(2): 353-377. doi:10.2307/2118443.

Harrison, J.S., Berman, S.L., 2016. "Corporate Social Performance and Economic Cycles." Journal of Business Ethics 138 (2): 279-294. https://doi.org/10.1007/s10551-015-26469

Hedberg, C J, and F Von Malmborg. 2003. "The Global Reporting Initiative and Corporate Sustainability Reporting in Swedish Companies." Corporate Social Responsibility and Environmental Management 10 (3): 153-64. doi:10.1002/csr.38.

Hughes, Alex, Martin Buttle, and Neil Wrigley. 2007. "Organisational Geographies of Corporate Responsibility: A UK-US Comparison of Retailers' Ethical Trading Initiatives." Journal of Economic Geography 7 (4): 491-513. doi:10.1093/jeg/lbm011.

Ioannou, I and Serafeim, G and Cheng, B. 2014. "Corporate Social Responsibility and Access to Finance." Strategic Management Journal, 1-23. 
doi:http://doi.org/10.1002/smj.2131.

Ioannou, loannis, and George Serafeim. 2012. "What Drives Corporate Social Performance the Role of Nation-Level Institutions." Journal of International Business Studies 43 (9): 834-64. doi:10.1057/jibs.2012.26.

Jarosiński, M., Puślecki, Ł., Trapczyński, P., 2016. "Competitiveness, Entrepreneurship and Economic Growth." In Competitiveness of CEE Economies and Businesses (pp. 25-44). Springer, Cham. https://doi.org/10.1007/978-3-319-39654-5

Jaworski, W. 2007. "Use of Extra-Financial Information by Research Analysts and Investment Managers." European Center for Corporate Engagement (ECCE), Maastricht University.

Jones, C. I. 2016. "The Facts of Economic Growth." In Handbook of Macroeconomics. doi:10.1016/bs.hesmac.2016.03.002.

Kim, Yongtae, and Meir Statman. 2012. "Do Corporations Invest Enough in Environmental Responsibility?" Journal of Business Ethics 105 (1): 115-29. doi:10.1007/s10551-0110954-2.

Kordalska, A.K., Olczyk, M., 2016. "Global competitiveness and economic growth: a one-way or two-way relationship?" Quarterly Journal of Economics and Economic Policy 11 (1): 121-142. https://doi.org/10.12775/EQUIL.2016.006

Kostova, Tatiana, and Srilata Zaheer. 1999 "Organizational legitimacy under conditions of complexity: The case of the multinational enterprise." Academy of Management review 24(1): 64-81.

Kozluk, T., Zipperer, V., 2015. "Environmental policies and productivity growth." OECD Journal: Economic Studies 2014 (1), 155-185. https://doi.org/10.1787/eco_studies2014-5jz2drqmi75j

Kwarteng, Amoako, Samuel Ato Dadzie, and Samuel Famiyeh. 2016. "Sustainability and Competitive Advantage from a Developing Economy." Journal of Global Responsibility 7 (1): 110-25. doi:10.1108/jgr-02-2016-0003.

Lee, K.H., Cin, B.C., Lee, E.Y., 2016. “Environmental Responsibility and Firm Performance: The Application of an Environmental, Social and Governance Model." Business Strategy 
and the Environment 25, 40-53. https://doi.org/10.1002/bse.1855

Lins, K. V., Servaes, H., Tamayo, A., 2017. "Social Capital, Trust, and Firm Performance: The Value of Corporate Social Responsibility during the Financial Crisis." The Journal of Finance 72 (4), 1785-1824. https://doi.org/10.1111/jofi.12505

López-Arceiz, F.J., Bellostas, A.J., Rivera, P., 2017. "Twenty Years of Research on the Relationship Between Economic and Social Performance: A Meta-analysis Approach." Social Indicators Research. https://doi.org/10.1007/s11205-017-1791-1

MacGillivray, A., J. Sabapathy, and S. Zadek. 2003. "Responsible Competitiveness Index 2003." AccountAbility and the Copenhagen Centre.

Madsen, M., and Ulhøi, J.P., 2017. Have Trends in Corporate Environmental Management Influenced Companies' Competitiveness? in Schaltegger, S. and Wagner, M. (eds.). Managing the Business Case for Sustainability. Routledge. London. UK. pp.256-274

Margolis, Joshua D, James P Walsh, Johnson Graduate, and James R Walsh. 2003. "Misery Loves Companies: Rethinking Social Initiatives by Business Misery Loves Companies: Rethinking Social Initiatives by." Administrative Science Quarter 48 (2): 268-305. doi:10.2307/3556659.

Mavragani, A., Nikolaou, I.E., Tsagarakis, K.P., 2016. "Open economy, institutional quality, and environmental performance: A macroeconomic approach." Mavragani, A., Nikolaou, I. E., \& Tsagarakis, K. P. (2016). Open economy, institutional quality, and environmental performance: A macroeconomic approach. Sustainability. 8, 1-13. https://doi.org/10.3390/su8070601

Mello, L. de. 2002. "Foreign Direct Investment-Led Growth: Evidence from Time Series and Panel Data." Oxford Economic Papers. doi:10.1093/oep/51.1.133.

MSCI. 2017a. "Foundations of ESG Investing." https://www.msci.com/documents/10199/03d6faef-2394-44e9-a119-4ca130909226. MSCI. 2017b. Country Classification Standard. https://www.msci.com/documents/1296102/1360895/8.5x11inch_MSCI_Country_Classif ication_Standard_FactSheet.pdf/5b95f2f4-4ced-43a2-92ad-218771a2218c

Murray, S. 2012. "Companies Try to Reduce Humanity's Footprint.” London: Sustainable 
Business Special Report. Financial Times.

Nahal, S, and V Lucas-Leclin. 2013. "Extreme Weather Primer - Weathering The Perfect Storm." London: Bank of America Merrill Lynch.

Ngobo, P.V., Fouda, M., 2012. "Is "Good" governance good for business? A cross-national analysis of firms in African countries." Ngobo, P. V., \& Fouda, M. (2012). Is 'Good'governance good for business? A cross-national analysis of firms in African countries. Journal of World Business. 47, 435-449.

https://doi.org/10.1016/j.jwb.2011.05.010

Nickell, Stephen. 1981. "Biases in Dynamic Panel Models with Fixed Effects." Econometrica. doi:10.2307/1911408.

Porter, M E, and M R Kramer. 2006. "Strategy and Society: The Link Between Competitive Advantage and Corporate Social Responsibility." Harvard Business Review December: 78-94.

Porter, M E, and C van der Linde. 1995. "Toward a New Conception of the EnvironmentCompetitiveness Relationship." The Journal of Economic Perspectives 9 (4): 97-118.

PWC. 2010. "CSR Trends in 2010: Stacking Up the Results." http://www.pwc.com/ca/en/sustainability/publications/csr-trends-2010-09.pdf: Price Waterhouse Coopers.

Renneboog, L, J T Horst, and C Zhang. 2008. "Socially Responsible Investments: Institutional Aspects, Performance, and Investor Behavior." Journal of Banking \& Finance 32: 1723-42.

Ribando, J. M., and G. Bonne. 2010. "A New Quality Factor: Finding Alpha With ASSET4 ESG Data." Starmine Research Note.

Richardson, Benjamin J. 2009. "Keeping Ethical Investment Ethical: Regulatory Issues for Investing for Sustainability." Journal of Business Ethics 87 (4): 555-72. doi:10.1007/s10551-008-9958-y.

Ringov, Dimo, and Maurizio Zollo. 2007. "The Impact of National Culture on Corporate Social Performance." Corporate Governance: The International Journal of Business in Society 7 (4): 476-85. doi:10.1108/14720700710820551. 
Rubashkina, Y., Galeotti, M., Verdolini, E., 2015. "Environmental regulation and competitiveness: Empirical evidence on the Porter Hypothesis from European manufacturing sectors." Energy Policy 83, 288-300. https://doi.org/10.1016/j.enpol.2015.02.014

Schwab, Klaus. 2018. “The Global Competitiveness Report 2018.” World Economic Forum Reports 2018. doi:ISBN-13: 978-92-95044-73-9.

Skouloudis, Antonis, David Isaac, and Kostis Evaggelinos. 2016. "Revisiting the National Corporate Social Responsibility Index." International Journal of Sustainable Development and World Ecology 23 (1): 61-70. doi:10.1080/13504509.2015.1099121.

Swift, T., and S. Zadek. 2002. "Corporate Responsibility and the Competitive Advantage of Nations." London.

Toya, Hideki, and Mark Skidmore. 2007. Economic development and the impacts of natural disasters. Economics letters, 94(1): 20-25.

Uecker-Mercado, Haylee, and Matthew Walker. 2012. "The Value of Environmental Social Responsibility to Facility Managers: Revealing the Perceptions and Motives for Adopting ESR." Journal of Business Ethics 110 (3): 269-84. doi:10.1007/s10551-011-1153-x.

UN PRI (UN Principles for Responsible Investment). 2018. Annual Report 2018. https://d8g8t13e9vf2o.cloudfront.net/Uploads/g/f/c/priannualreport_605237.pdf

Willard, B. 2012. The New Sustainability Advantage: Seven Business Case Benefits of a Triple Bottom Line. New Society Publishers.

Wilmshurst, Trevor D., and Geoffrey R. Frost. 2000. "Corporate Environmental Reporting: A Test of Legitimacy Theory." Accounting, Auditing \& Accountability Journal. Vol. 13. doi:10.1108/09513570010316126.

Wong, Poh Kam, Yuen Ping Ho, and Erkko Autio. 2005. "Entrepreneurship, Innovation and Economic Growth: Evidence from GEM Data." Small Business Economics. doi:10.1007/s11187-005-2000-1.

Yu, E.P. yi, Guo, C.Q., Luu, B. Van, 2018. "Environmental, social and governance transparency and firm value." Business Strategy and the Environment. 27, 987-1004. https://doi.org/10.1002/bse.2047 
Zadek, Simon. 2006. "Responsible Competitiveness: Reshaping Global Markets through Responsible Business Practices." Corporate Governance: The International Journal of Business in Society. doi:10.1108/14720700610689469.

Zárate-Marco, A., Vallés-Giménez, J., 2015. "Environmental tax and productivity in a decentralized context: new findings on the Porter hypothesis." European journal of law and economics. 40, 313-339. https://doi.org/10.1007/s10657-013-9400-5 
Table 1 Summary of micro-economic E, S, and G score by country

\begin{tabular}{|c|c|c|c|c|c|c|c|}
\hline \multirow[t]{2}{*}{ Country } & \multicolumn{2}{|c|}{ Environmental score } & \multicolumn{2}{|c|}{ Social score } & \multicolumn{2}{|c|}{ Governance score } & \multirow[t]{2}{*}{ No. firms } \\
\hline & Mean & St. d & Mean & St. d & Mean & St. d & \\
\hline UNITED STATES & 46.09 & 2.37 & 50.33 & 2.91 & 49.98 & 0.32 & 2520 \\
\hline JAPAN & 56.89 & 3.71 & 44.56 & 2.70 & 50.09 & 0.25 & 430 \\
\hline UNITED KINGDOM & 59.02 & 2.75 & 56.87 & 1.60 & 50.44 & 1.00 & 402 \\
\hline AUSTRALIA & 49.27 & 9.38 & 51.22 & 4.90 & 51.87 & 2.30 & 383 \\
\hline CANADA & 46.87 & 6.64 & 49.64 & 4.92 & 48.66 & 1.55 & 311 \\
\hline CHINA & 40.05 & 5.99 & 37.27 & 7.99 & 49.91 & 0.80 & 241 \\
\hline SOUTH AFRICA & 61.36 & 11.96 & 67.29 & 10.17 & 50.53 & 0.85 & 127 \\
\hline SOUTH KOREA & 58.05 & 5.99 & 55.05 & 5.89 & 49.95 & 2.20 & 120 \\
\hline INDIA & 51.83 & 5.27 & 58.23 & 6.44 & 49.55 & 0.40 & 103 \\
\hline FRANCE & 71.78 & 6.40 & 65.85 & 4.40 & 49.70 & 0.58 & 102 \\
\hline GERMANY & 61.90 & 3.93 & 62.45 & 5.39 & 50.00 & 1.23 & 102 \\
\hline BRAZIL & 60.50 & 8.00 & 63.58 & 11.45 & 49.22 & 1.97 & 92 \\
\hline SWEDEN & 62.81 & 7.16 & 59.53 & 3.22 & 50.53 & 0.76 & 72 \\
\hline SWITZERLAND & 56.18 & 4.09 & 53.33 & 3.41 & 47.83 & 1.49 & 69 \\
\hline ITALY & 54.97 & 6.84 & 57.73 & 4.89 & 48.35 & 1.37 & 51 \\
\hline SPAIN & 66.80 & 6.88 & 67.38 & 6.40 & 49.95 & 1.39 & 47 \\
\hline MEXICO & 51.76 & 14.62 & 50.12 & 14.50 & 50.11 & 1.83 & 43 \\
\hline INDONESIA & 43.46 & 4.31 & 55.73 & 4.19 & 50.24 & 1.01 & 40 \\
\hline NETHERLANDS & 63.75 & 4.06 & 65.66 & 2.88 & 52.36 & 2.03 & 40 \\
\hline POLAND & 44.28 & 10.75 & 39.66 & 4.68 & 49.88 & 0.69 & 34 \\
\hline RUSSIAN & 51.25 & 10.63 & 45.57 & 8.98 & 49.19 & 2.25 & 33 \\
\hline BELGIUM & 55.97 & 3.62 & 49.98 & 2.62 & 48.57 & 1.12 & 29 \\
\hline DENMARK & 53.56 & 8.58 & 49.25 & 8.67 & 49.46 & 0.78 & 28 \\
\hline TURKEY & 53.55 & 9.82 & 54.66 & 7.01 & 50.46 & 0.50 & 28 \\
\hline NORWAY & 56.56 & 5.64 & 59.18 & 3.95 & 49.51 & 1.58 & 27 \\
\hline FINLAND & 63.51 & 9.01 & 57.67 & 4.74 & 51.58 & 0.93 & 26 \\
\hline GREECE & 53.71 & 5.97 & 48.28 & 3.50 & 49.21 & 1.78 & 18 \\
\hline AUSTRIA & 52.79 & 7.36 & 53.84 & 4.95 & 50.14 & 2.89 & 16 \\
\hline IRELAND & 50.75 & 5.23 & 49.77 & 5.19 & 41.06 & 2.75 & 14 \\
\hline PORTUGAL & 58.62 & 10.89 & 59.51 & 11.23 & 48.62 & 6.14 & 10 \\
\hline
\end{tabular}


Variable (1)

Environmental

Score

Social Score

Asset 4

ESG

Score

Governance score

We use Thomson Reuters Asset4 Environmental scores as indicators of microeconomic environmental performance. The environmental score covers 3 categories: resource use, emissions, and innovation, which largely come from corporate, public repoting (annual repors, corporate social responsibility (CSR) reports, company websites, and global media sources). We use Thomson Reuters Asset4 Social scores as indicators of micro-economic social performance. The social score covers 4 categories: work force, human rights, community and produ responsibility. Data largely derives from corporate, public reporting (annual reports, corporate social responsibility (CSR) reports, company websites, and global media sources).

We use Thomson Reuters Asset 4 Governance scores as indicato of microeconomic governance performance. The governance score covers 3 categories: management, shareholders, and CSR strategy. Data largely derives from corporate, public reporting (annual reports, corporate social responsibility (CSR) reports, company websites, and global media sources).
Measurement (3)

Data source (4)

Thomson Reuters ESG scores cover over 6,500 companies globally for the period of 2002-2017,

which allows us to conduct micro-economic ESG performance analysis in a global context in the last

15 years. We construct an equal weighted mean of $\mathrm{E}$ scores separately by country at year $\mathrm{t}$ that

measures the average micro-economic environmental performance of firms based in a given country,

for all observed countries and times.

Thomson Reuters ESG score covers over 6,500 companies globally for the period of 2002-2017,

which allows us to conduct micro-economic ESG performance analysis in a global context in the last 15 years. We construct an equal weighted mean of $S$ scores separately by country at year $t$ that measures the average micro-economic social performance of firms based in a given country, for all observed countries and times.

Thomson Reuters ESG score covers over 6,500 companies globally for the period of 2002-2017, which allows us to conduct micro-economic ESG performance analysis in a global context in the last 15 years. We construct an equal weighted mean of $\mathrm{G}$ scores separately by country at year $t$ that measures the average micro-economic governance performance of firms based in a given country, for all observed countries and times.
Thomson Reuters

Thomson Reuters

GDP per capita is gross domestic product (GDP) divided by midyear population. GDP is the sum of gross value added by all resident producers in the economy plus any product taxes and minus any subsidies not included in the value of the products. Data are in constant local currency.

\section{Dependent $\quad$ Product per Capita}

variable

Product per Capita

Gross domestic product per Capita is the change or trend in a

informal measure of a nation's prosperity.
Total MV (logged)

Total market value (MV) refers to the total market capitalization of listed domestic companies (US\$) in a country.

FDI (logged net

inflows)

Controls

Foreign direct investment refers to direct investment equity flows in an economy. In this study (US\$), we use net inflows (inward investment less outward investment) as an indicator of investment.

Inflation
Inflation is measured by consumer price index (CPI). It is defined as the change in the prices of a basket of goods and services that are typically purchased by specific groups of households
Market capitalization (also known as market value) is the share price times the number of shares outstanding (including their several classes) for listed domestic companies. Investment funds, unit trusts, and companies whose only business goal is to hold shares of other listed companies are excluded. Data are end of year values converted to U.S. dollars using corresponding year-end foreign exchange rates.

FDI is calculated as the aggregate equity capital, reinvestment of earnings, and other capital. Direct investment is a category of cross-border investment associated with a resident in one economy having control or a significant degree of influence on the management of an enterprise that is resident in another economy. Ownership equal to or above $10 \%$ of the ordinary shares of voting stock is included.

Inflation is measured in terms of the annual growth rate and in index, 2015 base year. Inflation measures the erosion of living standards.
World Bank

World Bank 
Table 3 Summary statistics

This table presents the basic summary statistics of all variables used for the period from 2002 to 2017. Our variables of interest are the mean of firm-level ESG scores by country: that is, environment scores, social scores and governance scores. The outcome variable is GDP per capita. Controls include total market value, net foreign direct investment, and CPI. Column 1 to Column 5 report the total observation, mean, standard deviation, minimum and maximum values, respectively.

\begin{tabular}{|c|c|c|c|c|c|c|}
\hline Variables & $\begin{array}{l}\text { Obs } \\
(1)\end{array}$ & & $\begin{array}{l}\text { Mean } \\
(2)\end{array}$ & $\begin{array}{l}\text { Std. Dev. } \\
\text { (3) }\end{array}$ & $\begin{array}{c}\text { Min } \\
(4)\end{array}$ & $\begin{array}{c}\operatorname{Max} \\
(5)\end{array}$ \\
\hline \multicolumn{7}{|l|}{ Micro-ESG scores } \\
\hline & overall & $N=450$ & 55.556 & 10.764 & 31.697 & 81.940 \\
\hline \multirow[t]{3}{*}{ Environment score } & between & 30 countries & & 7.534 & 40.015 & 71.783 \\
\hline & within & $2002-2017$ & & 7.796 & 28.636 & 84.096 \\
\hline & overall & $N=450$ & 55.014 & 10.087 & 26.882 & 84.593 \\
\hline \multirow[t]{3}{*}{ Social score } & between & 30 countries & & 7.840 & 37.270 & 69.740 \\
\hline & within & $2002-2017$ & & 6.488 & 31.208 & 84.957 \\
\hline & overall & $N=450$ & 49.633 & 2.607 & 34.199 & 57.079 \\
\hline \multirow[t]{2}{*}{ Governance score } & between & 30 countries & & 1.869 & 41.064 & 52.364 \\
\hline & within & $2002-2017$ & & 1.846 & 35.215 & 58.095 \\
\hline \multicolumn{7}{|l|}{ Outcome Variables } \\
\hline & overall & $N=450$ & 11.530 & 2.019 & 8.846 & 17.441 \\
\hline \multirow[t]{2}{*}{ GDP per capita (logged) } & between & 30 countries & & 2.045 & 9.012 & 17.139 \\
\hline & within & $2002-2017$ & & 0.123 & 10.835 & 12.102 \\
\hline \multicolumn{7}{|l|}{ Control Variables } \\
\hline & overall & $\mathrm{N}=450$ & 26.805 & 1.499 & 23.051 & 30.940 \\
\hline \multirow[t]{3}{*}{ Total MV (logged) } & between & 30 countries & & 1.452 & 23.858 & 30.546 \\
\hline & within & $2002-2017$ & & 0.446 & 24.950 & 28.057 \\
\hline & overall & $N=450$ & 24.741 & 0.734 & 20.538 & 27.362 \\
\hline \multirow[t]{3}{*}{ FDI (logged) } & between & 30 countries & & 0.555 & 24.155 & 26.370 \\
\hline & within & $2002-2017$ & & 0.490 & 20.791 & 26.372 \\
\hline & overall & $\mathrm{N}=450$ & 3.016 & 3.492 & -4.478 & 44.964 \\
\hline \multirow[t]{2}{*}{ CPI } & between & 30 countries & & 2.654 & 0.130 & 11.579 \\
\hline & within & $2002-2017$ & & 2.314 & -3.217 & 36.402 \\
\hline
\end{tabular}


Table 4 Correlation matrix

\begin{tabular}{l|ccccccc} 
& $\begin{array}{c}\text { GDP per } \\
\text { Capita }\end{array}$ & $\begin{array}{c}\text { Environment } \\
\text { score }\end{array}$ & $\begin{array}{c}\text { Social } \\
\text { score }\end{array}$ & $\begin{array}{c}\text { Governance } \\
\text { score }\end{array}$ & $\begin{array}{c}\text { Total MV } \\
\text { (logged) }\end{array}$ & Net FDI & CPI \\
\hline & & & & & & \\
GDP per Capita & 1 & & & & & & \\
Environment score & -0.082 & 1 & & & & & \\
Social score & -0.048 & 0.741 & 1 & & & & \\
Governance score & 0.081 & 0.118 & 0.136 & 1 & & \\
Total MV (logged) & -0.097 & -0.068 & -0.092 & 0.072 & 1 & & \\
Net FDI & -0.220 & -0.129 & -0.058 & -0.004 & 0.502 & 1 & \\
CPI & 0.030 & -0.221 & -0.072 & 0.015 & -0.112 & -0.037 & 1
\end{tabular}


Table 5 The main results of the firm-level ESG performance effect on macroeconomic growth

This table show estimates of the firm ESG performance effect on national economic growth across the whole sample. Columns (1) to (3) report the estimated coefficients and t statistics from the one-year lagged difference GMM estimator and column (4) to (6) report the estimated coefficients and t statistics from the one-year lagged system GMM estimator. Our variables of interest are firm-level ESG performance indicators, averaged by country, which are derived from Asset 4 environmental, social, and governance scores respectively. The outcome variable is the natural logarithm of GDP per capita. Controls include total market value, net foreign direct investment, and CPI. All variables are defined in Table 2. *,**, and $* * *$ denote statistical significance at the $10 \%, 5 \%$ and $1 \%$ levels, respectively.

\begin{tabular}{|c|c|c|c|c|c|c|}
\hline \multirow{3}{*}{ Dependent variable } & \multicolumn{6}{|c|}{ GDP per Capita (log) } \\
\hline & \multicolumn{3}{|c|}{ Difference GMM Estimator } & \multicolumn{3}{|c|}{ System GMM Estimator } \\
\hline & $(1)$ & $(2)$ & (3) & (4) & $(5)$ & $(6)$ \\
\hline \multirow[t]{2}{*}{ Environment score } & $0.0006 * * *$ & & & $0.0006 * * *$ & & \\
\hline & $(3.02)$ & & & $(3.09)$ & & \\
\hline \multirow[t]{2}{*}{ Social score } & & $0.0009 * * *$ & & & $0.0010 * * *$ & \\
\hline & & $(3.94)$ & & & $(3.89)$ & \\
\hline \multirow[t]{2}{*}{ Governance score } & & & $0.0016 * *$ & & & $0.0019 * * *$ \\
\hline & & & $(2.03)$ & & & $(1.89)$ \\
\hline \multirow[t]{2}{*}{ Lagged one-year GDP } & $0.906 * * *$ & $0.913 * * *$ & $0.899 * * *$ & $1.032 * * *$ & $1.033 * * *$ & $1.029 * * *$ \\
\hline & $(61.63)$ & $(60.52)$ & $(62.82)$ & $(221.38)$ & $(220.24)$ & $(229.40)$ \\
\hline \multirow[t]{2}{*}{ Total MV (logged) } & $0.026 * * *$ & $0.027 * * *$ & $0.026 * * *$ & $0.013 * * *$ & $0.014 * * *$ & $0.011 * * *$ \\
\hline & $(6.37)$ & $(6.55)$ & $(6.36)$ & $(3.83)$ & $(3.91)$ & $(3.28)$ \\
\hline \multirow[t]{2}{*}{ FDI (logged) } & $0.006^{* *}$ & $0.006 * *$ & $0.006 * *$ & $0.011 * * *$ & $0.011 * * *$ & $0.011 * * *$ \\
\hline & $(2.55)$ & $(2.41)$ & $(2.40)$ & $(4.42)$ & $(4.32)$ & $(4.36)$ \\
\hline \multirow[t]{2}{*}{ CPI } & $-0.004 * * *$ & $-0.004 * * *$ & $-0.004 * * *$ & $-0.001 *$ & $-0.001 *$ & $-0.002 * *$ \\
\hline & $(-5.37)$ & $(-5.22)$ & $(-5.80)$ & $(-1.68)$ & $(-1.70)$ & $(-2.40)$ \\
\hline \multirow[t]{2}{*}{ Year08 } & 0.001 & 0.002 & 0.001 & $-0.010 * * *$ & $-0.009 * *$ & $-0.011 * * *$ \\
\hline & $(0.29)$ & $(0.38)$ & $(0.17)$ & $(-2.70)$ & $(-2.55)$ & $(-3.13)$ \\
\hline \multirow[t]{2}{*}{ Year09 } & $-0.056 * * *$ & $-0.056 * * *$ & $-0.056 * * *$ & $-0.060 * * *$ & $-0.060 * * *$ & $-0.061 * * *$ \\
\hline & $(-14.83)$ & $(-14.56)$ & $(-15.07)$ & $(-15.88)$ & $(-15.73)$ & $(-16.53)$ \\
\hline \multirow[t]{2}{*}{ Year } & $-0.001 * *$ & $-0.001 * *$ & -0.000 & $-0.003 * * *$ & $-0.003 * * *$ & $-0.002 * * *$ \\
\hline & $(-2.18)$ & $(-2.39)$ & $(-1.52)$ & $(-9.84)$ & $(-9.98)$ & $(-9.58)$ \\
\hline Observations & 450 & 450 & 450 & 450 & 450 & 450 \\
\hline No. of Country & 30 & 30 & 30 & 30 & 30 & 30 \\
\hline
\end{tabular}




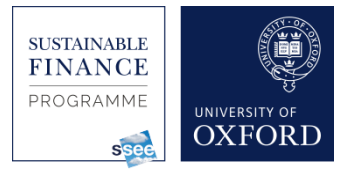

Table 6 The results of the firm ESG performance effect on macroeconomic growth by market

This table show estimates of the firm ESG performance effect on national economic growth by country type using the system GMM estimator. Columns (1) to (3) report the estimated coefficients and $t$-statistics for developed markets and columns (4) to (6) report the estimated coefficients and $t$-statistics for emerging economies. Our variables of interest are firm ESG performance indicators, averaged by country, which are derived from Asset4 environmental, social, and governance scores respectively. The outcome variable is the natural logarithm of GDP per capita. Controls include total market value, net foreign direct investment, and CPI. All variables are defined in Table $2 .{ }^{*},{ }^{* *}$, and ${ }^{* * *}$ denote statistical significance at the $10 \%, 5 \%$ and $1 \%$ levels, respectively.

\begin{tabular}{|c|c|c|c|c|c|c|}
\hline \multirow[t]{3}{*}{ Dependent variable } & \multicolumn{6}{|c|}{ GDP per Capita (log) } \\
\hline & \multicolumn{3}{|c|}{ Developed markets } & \multicolumn{3}{|c|}{ Emerging market } \\
\hline & $(1)$ & $(2)$ & (3) & $(4)$ & $(5)$ & $(6)$ \\
\hline \multirow[t]{2}{*}{ Environment score } & -0.0001 & & & $0.0012^{* * *}$ & & \\
\hline & $(-0.22)$ & & & $(3.80)$ & & \\
\hline \multirow[t]{2}{*}{ Social score } & & $0.0007 * *$ & & & $0.0011 * * *$ & \\
\hline & & $(2.21)$ & & & $(3.14)$ & \\
\hline \multirow[t]{2}{*}{ Governance score } & & & 0.0003 & & & $0.0026^{* *}$ \\
\hline & & & $(0.48)$ & & & $(2.20)$ \\
\hline \multirow[t]{2}{*}{ Lagged one-year GDP } & $0.987 * * *$ & $0.991 * * *$ & $0.991 * * *$ & $0.863 * * *$ & $0.876^{* * *}$ & $0.886^{* * *}$ \\
\hline & $(26.27)$ & $(26.51)$ & $(26.43)$ & $(35.46)$ & $(36.22)$ & $(37.08)$ \\
\hline \multirow[t]{2}{*}{ Total MV (logged) } & $0.019 * * *$ & $0.021 * * *$ & $0.019 * * *$ & $0.024 * * *$ & $0.025^{* * *}$ & $0.022 * * *$ \\
\hline & $(3.51)$ & $(3.90)$ & $(3.53)$ & $(4.17)$ & $(4.20)$ & $(3.84)$ \\
\hline \multirow[t]{2}{*}{ FDI (logged) } & $0.006 * * *$ & $0.006 * * *$ & $0.006 * * *$ & 0.012 & 0.008 & 0.011 \\
\hline & $(2.91)$ & $(3.01)$ & $(2.93)$ & $(1.45)$ & $(1.01)$ & $(1.34)$ \\
\hline \multirow[t]{2}{*}{ CPI } & $-0.004 * * *$ & $-0.004 * * *$ & $-0.004 * * *$ & $-0.004 * * *$ & $-0.004 * * *$ & $-0.005 * * *$ \\
\hline & $(-3.58)$ & $(-3.49)$ & $(-3.59)$ & $(-4.35)$ & $(-4.51)$ & $(-5.10)$ \\
\hline \multirow[t]{2}{*}{ Year08 } & $-0.008^{*}$ & $-0.008^{*}$ & $-0.009^{*}$ & 0.012 & 0.010 & 0.007 \\
\hline & $(-1.75)$ & $(-1.73)$ & $(-1.83)$ & $(1.48)$ & $(1.30)$ & $(0.94)$ \\
\hline \multirow[t]{2}{*}{ Year09 } & $-0.065 * * *$ & $-0.065^{* * *}$ & $-0.065^{* * *}$ & $-0.046 * * *$ & $-0.050 * * *$ & $-0.052 * * *$ \\
\hline & $(-14.34)$ & $(-14.54)$ & $(-14.52)$ & $(-6.30)$ & $(-6.89)$ & $(-7.43)$ \\
\hline \multirow[t]{2}{*}{ Year } & $-0.001 *$ & $-0.001 * * *$ & $-0.001 * *$ & 0.001 & 0.001 & -0.000 \\
\hline & $(-1.77)$ & $(-3.18)$ & $(-2.44)$ & (1.13) & $(0.70)$ & $(-0.55)$ \\
\hline Observations & 285 & 285 & 285 & 165 & 165 & 165 \\
\hline No. of Country & 19 & 19 & 19 & 11 & 11 & 11 \\
\hline
\end{tabular}


Table 7 The results of the firm ESG performance effect on macroeconomic growth: Robustness check

This table reports results of the firm ESG performance effect on macroeconomic growth across the whole sample using two-year lagged dynamic GMM estimators. Columns (1) to (3) report the estimated coefficients and $t$-statistics from the difference GMM estimator and columns (4) to (6) report the estimated coefficients and t-statistics from the system GMM estimator. Our variables of interest are firm ESG performance indicators, averaged by country, which are derived from Asset4 environmental, social, and governance scores respectively. The outcome variable is the natural logarithm of GDP per capita. Controls include total market value, net foreign direct investment, and CPI. All variables are defined in Table 2. *, ${ }^{* *}$, and *** denote statistical significance at the $10 \%, 5 \%$ and $1 \%$ levels, respectively.

\begin{tabular}{|c|c|c|c|c|c|c|}
\hline \multirow{3}{*}{ Dependent variable } & \multicolumn{6}{|c|}{ GDP per Capita (log) } \\
\hline & \multicolumn{3}{|c|}{ Difference GMM Estimator } & \multicolumn{3}{|c|}{ System GMM Estimator } \\
\hline & (1) & (2) & (3) & (4) & (5) & (6) \\
\hline \multirow[t]{2}{*}{ Environment score } & $0.001 * *$ & & & $0.001 * *$ & & \\
\hline & $(2.26)$ & & & $(2.20)$ & & \\
\hline \multirow[t]{2}{*}{ Social score } & & $0.001 * * *$ & & & $0.001 * * *$ & \\
\hline & & $(3.39)$ & & & $(2.92)$ & \\
\hline \multirow[t]{2}{*}{ Governance score } & & & $0.002 * *$ & & & $0.002 * *$ \\
\hline & & & $(2.07)$ & & & $(2.03)$ \\
\hline \multirow[t]{2}{*}{ Lagged one-year GDP } & $1.110^{* * *}$ & $1.108^{* * *}$ & $1.110^{* * *}$ & $1.338 * * *$ & $1.331^{* * *}$ & $1.339 * * *$ \\
\hline & (23.69) & $(23.55)$ & (23.82) & (42.19) & (41.90) & $(42.20)$ \\
\hline \multirow[t]{2}{*}{ Lagged two-year GDP } & $-0.195 * * *$ & $-0.186 * * *$ & $-0.204 * * *$ & $-0.304 * * *$ & $-0.295 * * *$ & $-0.308 * * *$ \\
\hline & $(-4.63)$ & $(-4.39)$ & $(-4.89)$ & $(-9.16)$ & $(-8.84)$ & $(-9.25)$ \\
\hline \multirow[t]{2}{*}{ Total MV (logged) } & $0.022 * * *$ & $0.022 * * *$ & $0.022 * * *$ & 0.002 & 0.002 & -0.001 \\
\hline & $(4.55)$ & $(4.66)$ & $(4.62)$ & $(0.43)$ & $(0.56)$ & $(-0.28)$ \\
\hline \multirow[t]{2}{*}{ FDI (logged) } & $0.005 * *$ & $0.005^{*}$ & $0.005 * *$ & 0.004 & 0.004 & 0.004 \\
\hline & $(2.09)$ & (1.93) & $(2.01)$ & $(1.46)$ & (1.34) & $(1.46)$ \\
\hline \multirow[t]{2}{*}{ CPI } & $-0.005 * * *$ & $-0.005 * * *$ & $-0.006 * * *$ & $-0.003 * * *$ & $-0.003 * * *$ & $-0.004 * * *$ \\
\hline & $(-6.49)$ & $(-6.42)$ & $(-6.73)$ & $(-3.98)$ & $(-3.97)$ & $(-4.54)$ \\
\hline \multirow[t]{2}{*}{ Year08 } & -0.001 & -0.001 & -0.001 & $-0.014 * * *$ & $-0.013 * * *$ & $-0.015^{* * *}$ \\
\hline & $(-0.17)$ & $(-0.13)$ & $(-0.18)$ & $(-3.56)$ & $(-3.38)$ & $(-3.91)$ \\
\hline \multirow[t]{2}{*}{ Year09 } & $-0.058 * * *$ & $-0.058 * * *$ & $-0.057 * * *$ & $-0.060 * * *$ & $-0.060 * * *$ & $-0.061 * * *$ \\
\hline & $(-14.73)$ & $(-14.72)$ & $(-14.68)$ & $(-14.87)$ & $(-14.93)$ & $(-15.27)$ \\
\hline \multirow[t]{2}{*}{ Year } & $-0.001 * *$ & $-0.001 * *$ & -0.001 & $-0.003 * * *$ & $-0.003 * * *$ & $-0.002 * * *$ \\
\hline & $(-2.04)$ & $(-2.38)$ & $(-1.49)$ & $(-8.23)$ & $(-8.60)$ & $(-8.15)$ \\
\hline Observations & 420 & 420 & 420 & 420 & 420 & 420 \\
\hline No. of Country & 30 & 30 & 30 & 30 & 30 & 30 \\
\hline
\end{tabular}


Table 8 The results of the firm ESG performance effect on the unemployment rate

This table reports results of the firm ESG performance effect on the national unemployment rate across the whole sample using one-year lagged dynamic GMM estimators. Columns (1) to (3) report the estimated coefficients and $t$-statistics from the difference GMM estimator and columns (4) to (6) report the estimated coefficients and $t$-statistics from the system GMM estimator. Our variables of interest are firm-level ESG performance indicators, averaged by country, which are derived from Asset4 environmental, social, and governance scores respectively. The outcome variable is the unemployment rate. Controls include total market value, net foreign direct investment, and CPI. All variables are defined in Table $2 .{ }^{*},{ }^{* *}$, and ${ }^{* * *}$ denote statistical significance at the $10 \%, 5 \%$ and $1 \%$ levels, respectively.

\begin{tabular}{|c|c|c|c|c|c|c|}
\hline \multirow{3}{*}{ Dependent variable } & \multicolumn{6}{|c|}{ Unemployment Rate } \\
\hline & \multicolumn{3}{|c|}{ Difference GMM Estimator } & \multicolumn{3}{|c|}{ System GMM Estimator } \\
\hline & (1) & (2) & (3) & (4) & (5) & (6) \\
\hline \multirow[t]{2}{*}{ Environment score } & $-1.751 * *$ & & & $-2.058 * *$ & & \\
\hline & $(-2.08)$ & & & $(-2.46)$ & & \\
\hline \multirow[t]{2}{*}{ Social score } & & $-2.062 * *$ & & & $-3.517 * * *$ & \\
\hline & & $(-2.25)$ & & & $(-3.80)$ & \\
\hline \multirow[t]{2}{*}{ Governance score } & & & 1.340 & & & -2.864 \\
\hline & & & $(0.50)$ & & & $(-1.09)$ \\
\hline \multirow[t]{2}{*}{ Lagged one year unemployment rate } & $0.730 * * *$ & $0.730 * * *$ & $0.722 * * *$ & $0.957 * * *$ & $0.962 * * *$ & $0.947 * * *$ \\
\hline & $(25.04)$ & $(24.92)$ & $(24.80)$ & $(61.89)$ & $(61.94)$ & $(64.80)$ \\
\hline \multirow[t]{2}{*}{ Total MV (logged) } & -0.065 & -0.076 & -0.015 & $-0.633 * * *$ & $-0.615 * * *$ & $-0.613 * * *$ \\
\hline & $(-0.40)$ & $(-0.46)$ & $(-0.09)$ & $(-7.47)$ & $(-7.09)$ & $(-7.20)$ \\
\hline \multirow[t]{2}{*}{ FDI (logged) } & $-0.368 * * *$ & $-0.369 * * *$ & $-0.365 * * *$ & $-0.449 * * *$ & $-0.452 * * *$ & $-0.462 * * *$ \\
\hline & $(-4.73)$ & $(-4.73)$ & $(-4.73)$ & $(-5.71)$ & $(-5.63)$ & $(-5.90)$ \\
\hline \multirow[t]{2}{*}{ CPI } & 0.034 & 0.034 & 0.039 & 0.033 & 0.034 & 0.041 \\
\hline & $(1.12)$ & $(1.12)$ & $(1.30)$ & $(1.19)$ & $(1.20)$ & $(1.52)$ \\
\hline \multirow[t]{2}{*}{ Year08 } & $-0.569 * * *$ & $-0.586 * * *$ & $-0.556^{* * *}$ & $-0.612 * * *$ & $-0.658^{* * *}$ & $-0.621 * * *$ \\
\hline & $(-2.97)$ & $(-3.05)$ & $(-2.92)$ & $(-3.43)$ & $(-3.62)$ & $(-3.52)$ \\
\hline \multirow[t]{2}{*}{ Year09 } & $1.310 * * *$ & $1.293 * * *$ & $1.312 * * *$ & $1.626^{* * *}$ & $1.604 * * *$ & $1.611 * * *$ \\
\hline & (7.18) & $(7.05)$ & $(7.25)$ & $(8.89)$ & $(8.60)$ & $(8.96)$ \\
\hline \multirow[t]{2}{*}{ Year } & 0.002 & 0.000 & -0.005 & $-0.024 * *$ & $-0.026^{* *}$ & $-0.027 * *$ \\
\hline & $(0.18)$ & $(0.03)$ & $(-0.36)$ & $(-1.98)$ & $(-2.15)$ & $(-2.27)$ \\
\hline Observations & 313 & 313 & 313 & 313 & 313 & 313 \\
\hline No. of Country & 29 & 29 & 29 & 29 & 29 & 29 \\
\hline
\end{tabular}


Pillar

Corporate Governance

Corporate Governance

Corporate Governance

Corporate Governance

Corporate Governance

Corporate Governance

Corporate Governance

Corporate Governance

Corporate Governance

Corporate Governance

Corporate $G 0$

Corporate Governance

Corporate Governance

Corporate Governance

Corporate Governance

Corporate Governance

Corporate Governance

Corporate Governance

Corporate Governance

Corporate Governance

Corporate Governance

Corporate Governance

Corporate Governance

Corporate Governance

Corporate Governance

Corporate Governance

Corporate Governance

Corporate Governance

Corporate Governance

Corporate Governance

Corporate Governance

Corporate Governance

Corporate Governance

Corporate Governance

Corporate Governance

Corporate Governance

Corporate Governance

Corporate Governance

Corporate Governance

Corporate Governance

Managemen

Theme

Management Board Functions

Management Board Functions

Management Board Functions

Management Board Functions

Management Board Functions

Management Board Functions

Management Board Functions

Management Board Functions

Management Board Functions

Management Board Functions

Management Board Functions

Management Board Functions

Management Board Functions

Management Board Functions

Management Board Functions

Management Board Functions

Management Board Functions

Management Board Functions

Management Board Functions

Management Board Functions

Management Board Functions

Management Board Structure

Management Board Structure

Management Board Structure

Management Board Structure

Management Board Structure

Management Board Structure

Management Board Structure

Management Board Structure

Management Board Structure

Management Board Structure

Management Board Structure

Management Board Structure

Management Board Structure

Management Board Structure

Management Board Structure

Management Board Structure

Management Board Structure

Management Board Structure

Management Board Structure

Management Board Structure

Management Board Structure

Management Board Structure

Management Board Structure

Corporate Governance

Corporate Governance

Corporate Governance

Corporate Governance
Indicator Description

Does the company have a policy for maintaining effective board functions?

Does the company have a corporate governance committee?

Percentage of independent board members on the audit committee as stipulated by the company.

Percentage of non-executive board members on the audit committee as stipulated by the company.

Percentage of independent board members on the compensation committee as stipulated by the company.

Percentage of non-executive board members on the compensation committee as stipulated by the company.

Percentage of independent board members on the nomination committee as stipulated by the company.

Percentage of non-executive board members on the nomination committee as stipulated by the company.

The number of board meetings during the year.

The average overall attendance percentage of board meetings as reported by the company.

The average overall attendance percentage of board committee meetings as reported by the company.

Does the company have a succession plan for executive management in the event of unforeseen circumstances?

Does the board or board committees have the authority to hire external advisers or consultants without management's approval?

Percentage of independent board members on the audit committee as stipulated by the company

Does the company report that all audit committee members are non-executives?

Does the company have an audit committee with at least three members and at least one "financial expert" within the meaning of Sarbanes-Oxley?

Percentage of independent board members on the compensation committee as stipulated by the company.

Does the company report that all compensation committee members are non-executives?

Percentage of non-executive board members on the nomination committee.

Are the majority of the nomination committee members non-executives?

Percentage of nomination committee members who are significant shareholders (more than 5\%).

Does the company publish information about the attendance of the individual board members at board meetings?

Does the company have a policy for maintaining a well-balanced membership of the board?

Does the company have a policy regarding the size of its board?

Does the company have a policy regarding the independence of its board?

Does the company have a policy regarding the diversity of its board?

Does the company have a policy regarding the adequate experience on its board?

Does the company have a nomination committee?

Does the company have a unitary board structure, a two-tier board structure with a supervisory board or a mixed board structure with a board of directors and a supervisory board?

Has the chairman previously held the CEO position in the company?

The total number of board members at the end of the fiscal year.

Is the board member the CEO?

The maximum number of years a board member can be on the board as stipulated by the company.

The smallest interval of years in which the board members are subject to re-election.

Total number of board members which are in excess of ten or below eight.

Does the company describe the professional experience or skills of every board member? OR Does the company provide information about the age of individual board members?

Percentage of female on the board.

Percentage of board members who have either an industry specific background or a strong financial background.

Average number of years each board member has been on the board.

Percentage of non-executive board members.

Percentage of independent board members as reported by the company.

Percentage of strictly independent board members (not employed by the company; not representing or employed by a majority shareholder; not served on the board for more than ten years; not a reference shareholder with more than $5 \%$ of holdings; no cross-board membership; no recent, immediate family ties to the corporation; not

Does the CEO simultaneously chair the board or has the chairman of the board been the CEO of the company?

Average number of other corporate affiliations for the board member.

Are all board member individually subject to re-election (no classified or staggered board structure)?

Compensation Policy Does the company have a policy for performance-oriented compensation that attracts and retain the senior executives and board members? 
Corporate Governance Corporate Governance Corporate Governance Corporate Governance

Corporate Governance Corporate Governance Corporate Governance Corporate Corporate Governance Corporate Governance Corporate Governance Corporate Governance Corporate Governance Corporate Corporate Governance Corporate Governance Corporate Governance Corporate Governance Corporate Governance Corporate Corporate Governance Corporate Governance Corporate Governance Corporate Governance Corporate Governance Corpora Corporate Governance Corporate Governance Corporate Governance Corporate Governance Corporate Governance Corporate Governance Corporate Governance Corporate Governance Corporate Governance Corporate Governance Corporate Corporate Governance Corporate Governance Corporate Governance Corporate Governance Corporate Governance Corporate Go Corporate Governance Corporate Governance Corporate Governance Corporate Governance Corporate Governance Corporate Governance Corporate Governance
Compensation Policy Compensation Policy Compensation Policy Compensation Policy Management Management

Management Management Management Manageme Managemen Management Management Management

Management

Managemen Managemen Managemen Management

Management

CSR strategy

CSR strategy

CSR strategy

CSR strategy

CSR strategy

CSR strategy

CSR strategy

CSR strateg

CSR strategy

CSR strategy

Shareholders

Shareholders

Shareholders

Shareholders

Shareholders

Shareholders

Shareholders

Shareholders

Shareholders

Shareholders

Shareholder

Shareholders

Shareholders

Shareholders

Shareholders

Shareholders

Shareholders

Shareholders

Shareholders

Shareholders

Shareholders

Shareholders

Compensation Policy

Compensation Policy

Policy

Compensation Policy

Compensation Policy

Compensation Policy

Compensation Policy

Compensation Policy

Compensation Policy

Compensation Policy

Compensation Policy

Compensation Policy

Compensation Policy

Vision \& Strategy

Vision \& Strategy

Vision \& Strategy

Vision \& Strategy

Vision \& Strategy

Vision \& Strategy

Vision \& Strategy

Vision \& Strategy

Vision \& Strategy

Shareholder Rights

Shareholder Rights

Shareholder Rights

Shareholder Rights

Shareholder Rights

Shareholder Rights

Shareholder Rights

Shareholder Rights

Shareholder Rights

Shareholder Rights

Shareholder Rights

Shareholder Rights

Shareholder Rights

Shareholder Rights

Shareholder Rights

Shareholder Rights

Shareholder Rights

Shareholder Rights

Shareholder Rights

Shareholder Rights

Shareholder Rights

Shareholder Rights
Does the company have a performance oriented compensation policy?

Does the company have an ESG related compensation policy?

Does the company have a compensation policy to attract and retain executives?

Does the company have a compensation committee?

Does the company have the necessary internal improvement and information tools for the board members to develop appropriate compensation/remuneration to attract and retain key executives?

Compensation Policy

The maximum time horizon of targets to reach full senior executives' compensation.

Is the CEO's compensation linked to total shareholder return (TSR)?

The maximum time horizon of the board member's targets to reach full compensation.

The total compensation of non-executive board members (if total aggregate is reported by the company).

The total compensation paid to all senior executives (if total aggregate is reported by the company).

Does the company require that shareholder approval is obtained prior to the adoption of any stock based compensation plans?

Number of controversies published in the media linked to high executive or board compensation.

Number of controversies published in the media linked to high executive or board compensation published since the last fiscal year company update.

Does the company provide information about the total individual compensation of all executives and board members?

Highest remuneration package within the company in US dollars.

Total compensation of the non-executive board members in US dollars.

Is the management and board members remuneration partly linked to objectives or targets which are more than two years forward looking?

Is the company under the spotlight of the media because of a controversy linked to high executive or board compensation?

Is the senior executive's compensation linked to CSR/H\&S/Sustainability targets?

Does the company have a CSR committee or team?

Does the company explicitly integrate financial and extra-financial factors in its management discussion and analysis (MD\&A) section in the annual report?

Has the company signed the UN Global Compact?

Does the company explain how it engages with its stakeholders?

Does the company publish a separate sustainability report or publish a section in its annual report on sustainability?

Is the company's sustainability report published in accordance with the GRI guidelines?

Does the company's sustainability report take into account the global activities of the company?

Does the company have an external auditor of its sustainability report?

The name of the external auditor of the sustainability report.

The percentage of the company's activities covered in its Environmental and Social reporting.

Does the company have a policy for ensuring equal treatment of minority shareholders, facilitating shareholder engagement or limiting the use of anti-takeover devices?

Does the company have a policy to apply the one-share, one-vote principle?

Does the company have a policy to facilitate shareholder engagement, resolutions or proposals?

Does the company have different class stocks with different voting rights?

Does the company have shares with a voting cap (ceilings) clause, ownership ceilings or control share acquisition provision?

The percentage of maximum voting rights allowed or ownership rights.

Has the company set requirements for a minimum number of shares to vote?

Are the company's board members elected with a majority vote?

Do the company's shareholders have the right to vote on executive compensation?

Are the company's articles of association, statutes or bylaws publicly available?

Does the biggest owner (by voting power) hold the veto power or own golden shares?

Is the company a State Owned Enterprise (SOE)?

Does the company have a poison pill (shareholder rights plan, macaroni defense, etc.)?

Does the company have unlimited authorized capital or a blank check?

Does the company have a classified board structure?

Does the company have a staggered board structure?

Does the company have a supermajority vote requirement or qualified majority (for amendments of charters and bylaws or lock-in provisions)?

Does the company have a golden parachute or other restrictive clauses related to changes of control (compensation plan for accelerated pay-out)?

Has the company limited the rights of shareholders to call special meetings?

Has the company reduced or eliminated cumulative voting in regard to the election of board members?

Does the company grant pre-emptive rights to existing shareholders?

Does the company have significant cross shareholding that can prevent takeovers? 
Corporate Governance Corporate Governance Corporate Governance Corporate Governance Corporate Governance Corporate Corporate Corporate Governance Corporate Governance Corporate Governance Corporate Governance Corporate Corporate Governance Corporate Governance

Environmenta Environmenta

Environmental

Environmental

Environmenta

Environmental

Environmental

Environmenta

Environmental

Environmental

Environmenta

Environmental

Environmental

Environmenta

Environmental

Environmental

Environmenta

Environmental

Environmental

Environmental

Environmental

Environmental

Environmenta

Environmenta

Environmental

Environmental

Environmental

Environmenta

Environmental

Environmental

Environmental

Environmental

Environmental

Environmenta

Environmental
Shareholder Rights Shareholder Rights Shareholder Rights Shareholder Rights Shareholder Rights Shareholder Rights Shareholder Rights Shareholder Rights Shareholder Rights Shareholder Rights Shareholder Rights Shareholder Rights Shareholder Rights Shareholder Rights Shareholder Rights

Emission Reduction Emission Reduction Emission Reduction Emission Reduction Emission Reduction Emission Reduction Emission Reduction Emission Reduction Emission Reduction Emission Reduction Emission Reduction Emission Reduction Emission Reduction Emission Reduction Emission Reduction Emission Reduction Emission Reduction Emission Reduction Emission Reduction Emission Reduction Emission Reduction Emission Reduction Emission Reduction Emission Reduction

Emission Reduction Emission Reduction Emission Reduction Emission Reduction Emission Reduction Emission Reduction Emission Reduction Emission Reduction Emission Reduction Emission Reduction Emission Reduction
Does the company have a confidential voting policy (i.e., management cannot view the results of shareholder votes)? Does the company have a limitation of director liability?

Number of controversies linked to shareholder rights infringements published in the media.

Number of controversies linked to shareholder rights infringements published since the last fiscal year company update.

Limitations to the shareholders right to approve significant company transitions such as M\&As (no rights to vote or supermajority required)?

Is the company subject to fair price provision, either under applicable law or as stated in the company documents (charter or bylaws)?

Are there limitations on the shareholders' right to remove board members (i.e., only for cause, supermajority vote required, etc.)?

Does the company have deadlines relating to shareholder proposals?

What is the minimum interval (in days) prior to the next shareholder meeting beyond which a shareholder proposal will not be accepted?

Does the company permit actions to be taken without meeting by written consent?

Does the company have expanded-constituency provisions in place?

The adoption date of the poison pill.

The expiration date of the poison pill.

Are all shares of the company providing equal voting rights?

The number of anti-takeover devices in place in excess of two.

Does the company have a policy to improve emissions reduction?

Has the company set targets or objectives to be achieved on emissions reduction?

Does the company report on its impact or on activities to reduce its impact on biodiversity?

Total $\mathrm{CO} 2$ and $\mathrm{CO} 2$ equivalents emissions

Direct $\mathrm{CO} 2$ and $\mathrm{CO} 2$ equivalents emissions

Indirect of $\mathrm{CO} 2$ and $\mathrm{CO} 2$ equivalents emissions

Total direct flaring or venting of natural gas emissions

Total $\mathrm{CO} 2$ and $\mathrm{CO} 2$ equivalents emission in tonnes per tonne of cement produced.

Total amount of ozone depleting (CFC-11 equivalents) substances emitted

Does the company report on initiatives to reduce, reuse, recycle, substitute, or phase out SOx (sulfur oxides) or NOx (nitrogen oxides) emissions?

Total amount of NOx emissions emitted

Total amount of SOx emissions emitted

Does the company report on initiatives to reduce, substitute, or phase out volatile organic compounds (VOC)?

Does the company report on initiatives to reduce, substitute, or phase out particulate matter less than ten microns in diameter (PM10)?

Total amount of volatile organic compounds (VOC) emissions

Total amount of waste produced

Total amount of non-hazardous waste produced

Total recycled and reused waste

Total amount of hazardous waste produced

Total volume of water discharged

Total weight of water pollutant emissions

Does the company report on initiatives to recycle, reduce, reuse, substitute, treat or phase out any type of waste?

Does the company report on initiatives to recycle, reduce, reuse, substitute, treat or phase out e-waste?

Does the company participate in any emissions trading initiative, as reported by the company?

Does the company report on partnerships or initiatives with specialized NGOs, industry organizations, governmental or supra-governmental organizations, which are focused on improving environmental issues?

Does the company claim to have a certified Environmental Management System?

The percentage of company sites or subsidiaries that are certified with any environmental management system.

Does the company report or provide information on sizable company-generated initiatives to restore the environment?

Does the company report on initiatives to reduce the environmental impact of transportation used for its staff?

Direct and accidental oil and other hydrocarbon spills

Is the company aware that climate change can represent commercial risks and/or opportunities?

Total amount of environmental expenditures.

Environmental provisions as reported within the balance sheet.

Does the company report on making environmental investments to reduce future risks or increase opportunities?

Total $\mathrm{CO} 2$ and $\mathrm{CO} 2$ equivalent Scope Three emissions 
Emission Reduction Emission Reduction Emission Reduction

Emission Reduction Emission Reduction Emission Reduction Emission Reduction

Emission Reduction

Emission Reduction

Product Innovatio

Product Innovation

Product Innovation

Product Innovation

Product Innovation

Product Innovation

Product Innovation

Product Innovation

Product Innovation

Product Innovation

Product Innovation

Product Innovation

Product Innovation

Product Innovation

Product Innovation

Product Innovation

Product Innovation

Product Innovation

Product Innovation

Product Innovation

Product Innovation

Product Innovation

Product Innovation

Product Innovation

Product Innovation

roduct Innovation

Product Innovation

Product Innovation Product Innovation

Product Innovation Resource Reduction Resource Reduction Resource Reduction
The equivalent of the $\mathrm{CO} 2$ offsets, credits and allowances purchased and/or produced by the company during the fiscal year.

The waste recycling ratio as reported by the company.

Environmental fines as reported by the company

The estimated total $\mathrm{CO} 2$ and $\mathrm{CO} 2$ equivalents emission in tonnes.

CO2 estimate method

TRBC code used to calculate estimate if the Median model is used

Total $\mathrm{CO} 2$ and $\mathrm{CO} 2$ equivalents emission in tonnes divided by net sales or revenue in US dollars.

Does the company report on initiatives to reduce, substitute, or phase out volatile organic compounds (VOC) or particulate matter less than ten microns in diameter PM10)?

Total amount of waste produced in tonnes divided by net sales or revenue in US dollars.

Total recycled and reused waste produced in tonnes divided by total waste produced in tonnes.

otal amount of hazardous waste produced in tonnes divided by net sales or revenue in US dollars.

Total weight of water pollutant emissions in tonnes divided by net sales or revenue in US dollars.

Does the company report on its environmental expenditures or does the company report to make proactive environmental investments to reduce future risks or increase future opportunities?

Does the company report on at least one product line or service that is designed to have positive effect on the environment or which is environmentally labeled and marketed?

(without clean up and remediation costs).

Does the company develop new products that are marketed as reducing noise emissions?

Total fleet's average fuel consumption in $1 / 100 \mathrm{~km}$

Is the company developing hybrid technology?

Total fleet's average $\mathrm{CO} 2$ and $\mathrm{CO} 2$ equivalent emissions in $\mathrm{g} / \mathrm{km}$.

Does the company report on ESG screeened Assets Under Management?

Is the company a signatory of the Equator Principles (commitment to manage environmental issues in project financing)?

Does the company claim to use ESG criteria as part of its investment or lending or underwriting decisions?

Does the company construct nuclear reactors, produce nuclear energy or extract uranium?

Percentage of total energy production from nuclear energy.

The percentage of labeled wood or forest products from total wood or forest products.

Does the company claim to produce or distribute wood or forest products that are labeled?

Does the company report or show initiatives to produce or promote organic food or other products?

Does the company reports about take-back procedures and recycling programs to reduce the potential risks of products entering the environment?

Does the company report about product features and applications or services that will promote responsible and environmentally preferable use?

Does the company produce or distribute genetically modified organisms (GMO)?

Does the company produce or distribute agrochemicals like pesticides, fungicides or herbicides?

Are the revenues generated by the company from agrochemicals $5 \%$ or more of company sales?

Is the company involved in animal testing?

Is the company involved in animal testing for cosmetics?

Has the company established a program or an initiative to minimize or phase out animal testing?

Is the company developing clean technology (wind, solar, hydro and geo-thermal and biomass power)?

Does the company develop products or technologies that are used for water treatment, purification or that improve water use efficiency?

Does the company develop products and services that improve the energy efficiency of buildings?

Does the company report on specific products which are designed for reuse, recycling or the reduction of environmental impacts?

Does the company claim to lease, rent or market buildings that are certified by BREEAM, LEED or any other nationally recognized real estate certification?

Total amount of environmental R\&D costs (without clean up and remediation costs) divided by net sales or revenue.

Is the company a signatory of the Equator Principles (commitment to manage environmental issues in project financing)? OR Does the company claim to evaluate projects on the basis of environmental or biodiversity risks as well?

Total energy distributed or produced from renewable energy sources divided by the total energy distributed or produced.

Does the company reports about take-back procedures and recycling programs to reduce the potential risks of products entering the environment? OR Does the company report about product features and applications or services that will promote responsible, efficient, cost-effective and environmentally preferable use?

Does the company have a policy for reducing the use of natural resources or to lessen the environmental impact of its supply chain?

Does the company set specific objectives to be achieved on resource efficiency?

Does the company have an environmental management team?

Does the company train its employees on environmental issues?

Does the company have a policy to improve its water efficiency? 
Resource Reduction Resource Reductio Resource Reduction Resource Reductio Resource Reduction Resource Reduction Resource Reduction Resource Reductio Resource Reduction Resource Reduction Resource Reduction Resource Reduction Resource Reduction Resource Reduction Resource Reduction Resource Reduction Resource Reduction Resource Reductio Resource Reduction Resource Reduction

Resource Reduction Resource Reduction Resource Reduction Resource Reduction Resource Reduction Resource Reductio Resource Reduction

Resource Reduction Resource Reduction Resource Reduction Resource Reduction Resource Reduction

Product Responsibility Product Responsibility Product Responsibility Product Responsibility Product Responsibility Product Responsibility Product Responsibility Product Responsibility Product Responsibility
Does the company have a policy to improve its energy efficiency?

Does the company have a policy to improve its use of sustainable packaging?

Does the company have a policy to include its supply chain in the company's efforts to lessen its overall environmental impact?

Has the company set targets or objectives to be achieved on water efficiency?

Has the company set targets or objectives to be achieved on energy efficiency?

Does the company claim to use environmental criteria to source materials?

Does the company report on initiatives to reduce, reuse, substitute or phase out toxic chemicals or substances?

Total direct and indirect energy consumption

Direct energy purchased

Direct energy produced

Indirect energy consumption

Electricity purchased

Electricity produced

Total energy use in gigajoules per tonne of clinker produced.

Total primary renewable energy purchased

Total primary renewable energy produced

Does the company make use of renewable energy?

Does the company report about environmentally friendly or green sites or offices?

Total water withdrawal

Total fresh water withdrawa

Amount of water recycled or reused

Does the company use environmental or sustainable criteria in the selection process of its suppliers or sourcing partners? Does the company report or show to be ready to end a partnership with a sourcing partner, in the case of severe environmental negligence and failure to comply with Doestandards?

Does the company report on initiatives to reduce

Amount of Natural Gas produced in million $\mathrm{m} 3$ (raw material)

Amount of Oil Produced in barrels (raw material)

Does the company conduct surveys of the environmental performance of its suppliers?

Number of controversies related to the environmental impact of the company's operations on natural resources or local communities.

Number of controversies related to the environmental impact of the company's operations on natural resources or local communities since the last fiscal year company update.

otal direct and indirect energy consumption in gigajoules divided by net sales or revenue in US dollars.

Total energy generated from primary renewable energy sources divided by total energy.

Total water withdrawal in cubic meters divided by net sales or revenue in US dollars.

Is the company under the spotlight of the media because of a controversy linked to the environmental impact of its operations on natural resources or local communities?

Does the company have a policy to protect customer health \& safety?

Does the company have a policy to protect customer and general public privacy and integrity?

Does the company have a policy on responsible marketing ensuring protection of children?

Does the company have a policy on fair trade?

Does the company monitor the impact of its products or services on consumers or the community more generally?

Does the company claim to have an ISO 9000 certification or any industry specific certification (QS-9000-automotive, TL 9000-telecommunications, AS9100-aerospace, SO/TS 16949-automotive, etc.)?

Does the company claim to apply the Six Sigma, Lean Manufacturing, Lean Sigma, TQM or any other similar quality principles?

Does the company distribute any low-priced products or services specifically designed for lower income categories? Does the company reportedly develop or market products and services that foster specific health and safety benefits for the consumers (healthy, organic or nutritional 


\begin{tabular}{|c|c|c|c|}
\hline Social & $\begin{array}{l}\text { Product } \\
\text { Prosponsibility } \\
\text { Product }\end{array}$ & Product Responsibility & Is the company directly or indirectly involved in embryonic stem cell research? \\
\hline Social & $\begin{array}{l}\text { responsibility } \\
\text { Product }\end{array}$ & Product Responsibility & Does the company claim to retail Alcohol or Tobacco? \\
\hline Social & $\begin{array}{l}\text { responsibility } \\
\text { Product }\end{array}$ & Product Responsibility & Does the company produce alcoholic beverages? \\
\hline Social & $\begin{array}{l}\text { responsibility } \\
\text { Product }\end{array}$ & Product Responsibility & The revenues generated by the company from the sale of alcohol. \\
\hline Social & $\begin{array}{l}\text { responsibility } \\
\text { Product }\end{array}$ & Product Responsibility & Does the company generate revenues from gambling? \\
\hline Social & $\begin{array}{l}\text { responsibility } \\
\text { Product }\end{array}$ & Product Responsibility & The revenues generated by the company from gambling. \\
\hline Social & $\begin{array}{l}\text { responsibility } \\
\text { Product }\end{array}$ & Product Responsibility & Does the company produce tobacco? \\
\hline Social & $\begin{array}{l}\text { responsibility } \\
\text { Product }\end{array}$ & Product Responsibility & The revenues generated by the company from the sale of tobacco. \\
\hline Social & $\begin{array}{l}\text { responsibility } \\
\text { Product }\end{array}$ & Product Responsibility & Does the company produce vehicles, planes, armaments or any combat materials used by the military? \\
\hline Social & $\begin{array}{l}\text { responsibility } \\
\text { Product }\end{array}$ & Product Responsibility & The revenues generated by the company from the sale of vehicles, planes, armaments and combat materials used by the military. \\
\hline Social & $\begin{array}{l}\text { responsibility } \\
\text { Product }\end{array}$ & Product Responsibility & Does the company produce or distribute pornography? \\
\hline Social & $\begin{array}{l}\text { responsibility } \\
\text { Product }\end{array}$ & Product Responsibility & Does the company produce hormonal contraceptives? \\
\hline Social & $\begin{array}{l}\text { responsibility } \\
\text { Product }\end{array}$ & Product Responsibility & Does the company claim to fight against the obesity risk? \\
\hline Social & $\begin{array}{l}\text { responsibility } \\
\text { Product }\end{array}$ & Product Responsibility & Number of controversies published in the media linked to customer health \& safety. \\
\hline Social & $\begin{array}{l}\text { responsibility } \\
\text { Product }\end{array}$ & Product Responsibility & Number of controversies published in the media linked to responsible $R \& D$. \\
\hline Social & $\begin{array}{l}\text { responsibility } \\
\text { Product }\end{array}$ & Product Responsibility & Number of controversies published in the media linked to employee or customer privacy and integrity. \\
\hline Social & $\begin{array}{l}\text { responsibility } \\
\text { Product }\end{array}$ & Product Responsibility & Number of controversies published in the media linked to the company's marketing practices, such as over marketing of unhealthy food to vulnerable consumers. \\
\hline Social & $\begin{array}{l}\text { responsibility } \\
\text { Product }\end{array}$ & Product Responsibility & Number of controversies published in the media linked to product access. \\
\hline Social & $\begin{array}{l}\text { responsibility } \\
\text { Product }\end{array}$ & Product Responsibility & Number of FDA warning letters received by the company. \\
\hline Social & $\begin{array}{l}\text { responsibility } \\
\text { Product }\end{array}$ & Product Responsibility & Total number of products or services which have been delayed. \\
\hline Social & $\begin{array}{l}\text { responsibility } \\
\text { Product }\end{array}$ & Product Responsibility & Total number of drugs which have not been approved by regulators or similar official bodies. \\
\hline Social & $\begin{array}{l}\text { responsibility } \\
\text { Product }\end{array}$ & Product Responsibility & Has the company announced a mass recall of products or has completely withdrawn a product due to defects or safety reasons? \\
\hline Social & $\begin{array}{l}\text { responsibility } \\
\text { Product }\end{array}$ & Product Responsibility & Are revenues generated from armaments larger than $5 \%$ of the total net revenues? \\
\hline Social & $\begin{array}{l}\text { responsibility } \\
\text { Product }\end{array}$ & Product Responsibility & Are revenues/energy generated from nuclear energy activities larger than $5 \%$ of the total revenues/energy? \\
\hline Social & $\begin{array}{l}\text { responsibility } \\
\text { Product }\end{array}$ & Product Responsibility & Are revenues generated from gambling activities larger than $5 \%$ of the total net revenues? \\
\hline Social & $\begin{array}{l}\text { responsibility } \\
\text { Product }\end{array}$ & Product Responsibility & Are revenues generated from tobacco production larger than $5 \%$ of the total net revenues? \\
\hline Social & $\begin{array}{l}\text { responsibility } \\
\text { Product }\end{array}$ & Product Responsibility & Are revenues generated from alcohol production larger than $5 \%$ of the total net revenues? \\
\hline Social & $\begin{array}{l}\text { responsibility } \\
\text { Product }\end{array}$ & Product Responsibility & Does the company produce cluster bombs? \\
\hline Social & $\begin{array}{l}\text { responsibility } \\
\text { Product }\end{array}$ & Product Responsibility & Does the company produce Anti-Personnel Landmines? \\
\hline Social & $\begin{array}{l}\text { responsibility } \\
\text { Product }\end{array}$ & Product Responsibility & Number of controversies linked to the elements driving product quality and responsibility published since the last fiscal year company update. \\
\hline Social & $\begin{array}{l}\text { responsibility } \\
\text { Product }\end{array}$ & Product Responsibility & Number of controversies linked to the elements driving product quality and responsibility published since the last fiscal year company update. \\
\hline Social & responsibility & Product Responsibility & Number of controversies linked to the elements driving product quality and responsibility published since the last fiscal year company update. \\
\hline
\end{tabular}


Number of controversies linked to the elements driving product quality and responsibility published since the last fiscal year company update.

Number of FDA Warning letters since the last fiscal year company update.

The percentage of company sites or subsidiaries that are certified with any widely acknowledged quality management system.

Does the company produce abortifacients?

Does the company claim to apply quality management systems, such as ISO 9000, Six Sigma, Lean Manufacturing, Lean Sigma, TQM or any other similar quality

s the company under the spotlight of the media because of a controversy linked to the company's marketing practices, such as over marketing of unhealthy food to vulnerable consumers?

Is the company under the spotlight of the media because of a controversy linked to its products or services quality and responsibility?

Total number of products or services which have been delayed or drugs which have not been approved by regulators or similar official bodies. Does the company describe in the code of conduct that it trives to be a fair competitor?

Does the company describe in the code of conduct that it strives to avoid bribery and corruption at all its operations?

Does the company describe in the code of conduct that it strives to maintain the highest level of general business ethics?

Does the company have appropriate communication tools to improve general business ethics?

Does the company have a provision for protecting whistleblowers?

Does the company have a policy to be involved in the local community in the countries of operation?

Does the company claim to follow the OECD Guidelines for Multinational Enterprises?

Is the company a supporter of the "Extractive Industries Transparency Initiative (EITI)"?

Total amount of all donations by the company.

Total community lending, financing and investments which are not considered donations.

Total amount of political donations, support of political candidates or contributions to parties as reported by the company.

Does the company foster employee engagement in voluntary community work?

Is the company selling some products or services at a discount to normal retail prices in emerging markets?

Does the company claim to conduct research and development on drugs for diseases in the developing world?

Number of controversies published in the media linked to patents and intellectual property infringements.

Does the company report on crisis management systems or reputation disaster recovery plans to reduce or minimize the effects of reputation disasters? customers)

Number of controversies published in the media linked to business ethics in general, political contributions or bribery and corruption.

Number of controversies published in the media linked to tax fraud, parallel imports or money laundering.

Number of controversies published in the media linked to anti-competitive behavior (e.g., anti-trust and monopoly), price-fixing or kickbacks.

Number of controversies published in the media linked to activities in critical, undemocratic countries that do not respect fundamental human rights principles.

Does the company have operations in Burma (Myanmar), Cuba, Iran, Sudan, or Syria (the US sanction regime)?

Number of controversies linked to public health or industrial accidents harming the health \& safety of third parties (non-employees and non-customers) published since the last fiscal year company update.

Number of controversies linked to business ethics in general, political contributions or bribery and corruption published since the last fiscal year company update.

Number of controversies linked to tax fraud, parallel imports or money laundering published since the last fiscal year company update.

Number of controversies linked to anti-competitive behavior (e.g., anti-trust and monopoly), price-fixing or kickbacks published since the last fiscal year company update. Number of controversies linked to activities in critical, undemocratic countries that do not respect fundamental human rights principles published since the last fiscal year company update.

Number of controversies linked to patents and intellectual property infringements published since the last fiscal year company update.

Has the company received an award for its social, ethical, community, or environmental activities or performance?

The total amount of lobbying contributions made by the company or its employees and representatives during the fiscal year.

Total amount of all donations divided by net sales or revenue.

Is the company under the spotlight of the media because of a controversy linked to bribery and corruption, political contributions, improper lobbying, money laundering arallel imports or any tax fraud?

Does the company have a policy for the exclusion of child, forced or compulsory labour, or to guarantee the freedom of association universally applied independent of

Does the company have a policy to ensure the freedom of association of its employees?

Does the company have a policy to avoid the use of child labor?

Does the company have a policy to avoid the use of forced labor? 
Workforce

Workforce

Workforce

Workforce

Workforce

Workforce

Workforce

Workforce

Workforce

Workforce

Workforce

Workforce

Workforce

Workforce

Workforce

Workforce

Workforce

Workforce

Workforce

Workforce

Workforce

Workforce

Workforce

Workforce

Workforce

Workforce

Workforce

Workforce

Workforce

Workforce

Workforce

Workforce

Workforce

Workforce
Human Rights Human Rights Human Rights Human Rights Human Rights Human Rights Human Rights Human Rights Human Rights Human Righ
Diversity \& Opportunity Diversity \& Opportunity Diversity \& Opportunity Diversity \& Opportunity Diversity \& Opportunity Diversity \& Diversity \& Opportunity Diversity \& Opportunity Diversity \& Opportunity Diversity \& Opportunity Diversity \& Opportunity Employment Quality Employment Quality Employment Quality Employment Quality Employment Quality Employment Quality Employment Quality Employment Quality Employment Quality Employment Quality Employment Quality Employment Quality Employment Quality Employment Quality

Employment Quality Health \& Safety Health \& Safety Health \& Safety Health \& Safety Health \& Safety Health \& Safety Health \& Safety Health \& Safety
Does the company have a policy to ensure the respect of human rights in general?

Does the company claim to comply with the fundamental human rights convention of the ILO or support the UN declaration of human rights?

Does the company report or show to use human rights criteria in the selection or monitoring process of its suppliers or sourcing partners?

s the company a member of the Ethical Trading Initiative (ETI)?

Does the company report or show to be ready to end a partnership with a sourcing partner if human rights criteria are not met?

Number of controversies published in the media linked to human rights issues.

Number of controversies published in the media linked to freedom of association issues.

Number of controversies published in the media linked to use of child labor issues.

Number of controversies linked to human rights issues published since the last fiscal year company update.

Number of controversies linked to use of child labor issues published since the last fiscal year company update.

Does the company have a policy to drive diversity and equal opportunity?

Has the company set targets or objectives to be achieved on diversity and equal opportunity?

Percentage of women employees

Percentage of new women employees.

Percentage of women managers.

The score of the company in the HRC corporate equality index from the Human Rights Campaign Foundation.

Does the company provide flexible working schemes?

Does the company claim to provide day care services for its employees?

Number of controversies published in the media linked to workforce diversity and opportunity (e.g., wages, promotion, discrimination and harassment).

Percentage of employees with disabilities or special needs.

Number of controversies linked to workforce diversity and opportunity (e.g., wages, promotion, discrimination and harassment) published since the last fiscal yea company update.

Total value of salaries and wages paid to all employees and officers, including all benefits, as reported by the company in its CSR reporting.

Number of employees as reported by the company in its CSR reporting.

Total value of the stock based compensation of employees during the year as reported by the company.

Percentage of employees represented by independent trade union organizations or covered by collective bargaining agreements.

Percentage of employee turnover.

Total number of announced layoffs by the company.

Has an important executive management team member or a key team member announced a voluntary departure (other than for retirement) or has been ousted? Has there has been a strike or an industrial dispute that led to lost working days?

Number of part-time employees.

Number of controversies published in the media linked to the company's relations with employees or relating to wages or wage disputes.

Number of controversies linked to the company's relations with employees or relating to wages or wage disputes published since the last fiscal year company update. CEO's total salary (or other highest salary) divided by average wage (Highest Salary (US dollars) /Average Salaries and Benefits in (US dollars)).

Employment growth over the last year.

Total number of announced lay-offs by the company divided by the total number of employees.

Is the company under the spotlight of the media because of a controversy linked to the company's employees, contractors or suppliers due to wage, layoff disputes or working conditions?

Does the company have a policy to improve employee health \& safety within the company and its supply chain?

Does the company have an employee health \& safety team?

Does the company train its executives or key employees on health \& safety?

Does the company train its executives or key employees on employee health \& safety in the supply chain?

Total hours of health \& safety training

Does the company have a policy to improve employee health \& safety?

Does the company have a policy to improve employee health \& safety in its supply chain?

Does the company have health and safety management systems in place like the OHSAS 18001 (Occupational Health \& Safety Management System)? 
Workforce

Workforce

Workforce

Workforce

Workforce

Workforce

Workforce

Workforce

Workforce

Workforce

Workforce

Workforce

Workforce

Workforce

Workforce

Workforce

Workforce

Workforce

Workforce

Workforce

Workforce

Workforce

Workforce

Workforce
Health \& Safety Health \& Safety Health \& Safety Health \& Safety Health \& Safety Health \& Safety Health \& Safety

Health \& Safety Health \& Safety Health \& Safety Health \& Safety Health \& Safety Health \& Safety Health \& Safety Health \& Safety Health \& Safety Health \& Safety Health \& Safety Health \& Safety Health \& Safety

Health \& Safety Training \& Draining \& Training \& Training \& Developmen Training \& Training \& Developmen Training \& Developmen Draining \& Training \& Draining \& Training \& Training \& Diversity \& Opportunity
Does the company show through the use of surveys or measurements that it is improving the level of employee health \& safety in its supply chain? Total number of injuries and fatalities including no-lost-time injuries relative to one million hours worked.

Number of injuries and fatalities including no-lost-time injuries reported for contractors relative to one million hours worked.

Number of injuries and fatalities including no-lost-time injuries reported for employees relative to one million hours worked.

Number of injuries and fatalities reported by employees and contractors while working for the company.

Number of injuries and fatalities reported for contractors while working for the company.

Number of injuries and fatalities reported for employees while working for the company.

Number of occupational diseases or any disease caused by continued exposure to conditions inherent in a person's occupation reported relative to one million hours

Number of employee fatalities resulting from operational accidents.

Number of contractor fatalities resulting from operational accidents.

Total number of injuries that caused the employees and contractors to lose at least a working day relative to one million hours worked.

Number of injuries that caused the contractors to lose at least a working day relative to one million hours worked.

Number of injuries that caused the employees to lose at least a working day relative to one million hours worked.

Number of lost working days of the employees and contractors.

Number of lost working days of the employees only.

Number of lost working days of the contractors only.

Does the company report on policies or programs on HIV/AIDS for the workplace or beyond?

Number of controversies published in the media linked to workforce health and safety.

Number of controversies linked to workforce health and safety published since the last fiscal year company update.

Total number of injuries and fatalities including no-lost-time injuries relative to one million hours worked.

Total lost days at work divided by total working days. (Refers to an employee absent from work because of incapacity of any kind, not just as the result of occupational injury or disease)

Does the company have a policy to support the skills training or career development of its employees?

Does the company have a policy to improve the skills training of its employees?

Does the company have a policy to improve the career development paths of its employees?

Average hours of training per year per employee.

Total training hours performed by all employees.

Total training costs from all the training performed by all employees.

Does the company claim to favor promotion from within?

Does the company claim to provide regular staff and business management training for its managers?

Does the company provide training in environmental, social or governance factors for its suppliers?

Training costs per employee in US dollars. 